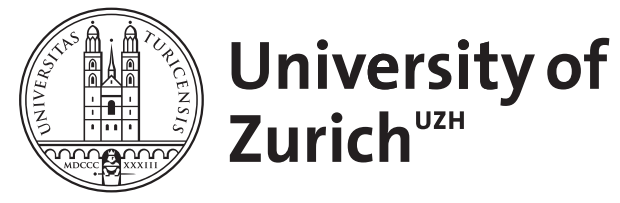
Archive

University of Zurich

University Library

Strickhofstrasse 39

CH-8057 Zurich

www.zora.uzh.ch

Year: 2001

\title{
Tetrahydrobiopterin in the vascular system
}

Walter, Roland ; Schaffner, Andreas ; Schoedon, Gabriele

DOI: https://doi.org/10.1515/pteridines.2001.12.3.93

Posted at the Zurich Open Repository and Archive, University of Zurich

ZORA URL: https://doi.org/10.5167/uzh-154663

Journal Article

Published Version

Originally published at:

Walter, Roland; Schaffner, Andreas; Schoedon, Gabriele (2001). Tetrahydrobiopterin in the vascular system. Pteridines, 12(3):93-120.

DOI: https://doi.org/10.1515/pteridines.2001.12.3.93 
Pteridines

Vol. 12,2001 , pp. $93-120$

\section{Tetrahydrobiopterin in the vascular system}

Roland Walter, Andreas Schaffner, Gabriele Schoedon

Department of Internal Medicine, Medical Clinic B, University Hospital, Zürich

\section{Introduction}

Since the initial description of a pteridine (Fig. 1) in
Nature 112 years ago,(1) numerous studies contributed to the current understanding of these small molecules as ubiquitous and essential compounds required for

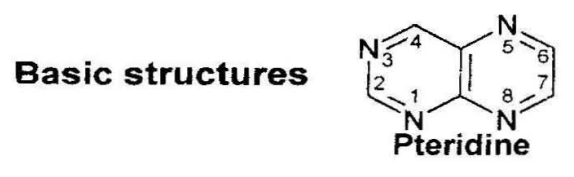<smiles>C[C@H](O)[C@@H](O)c1cnc2nc(N)[nH]c(=O)c2n1</smiles><smiles>CC(O)C(=O)C1CNc2nc(N)[nH]c(=O)c2N1</smiles>

\section{Unconjugated pteridines}<smiles>Nc1nc2nccnc2c(=O)[nH]1</smiles><smiles>Nc1nc2ncc([C@H](O)[C@H](O)CO)nc2c(=O)[nH]1</smiles>

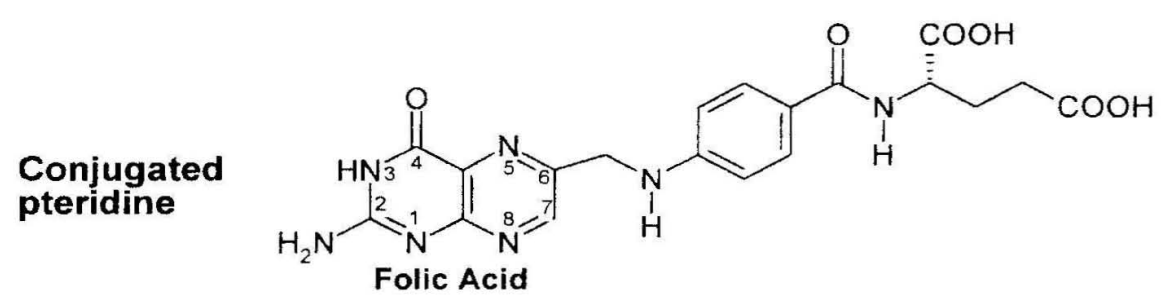

Figure 1. Chemical structures. "Pteridine" denotes the pyrazino-2,3-d-pyrimidine ring system underlying these molecules. The majority of the naturally occurring unconjugated pteridines, e.g. biopterin, neopterin, or sepiapterin, are derivatives of the 2-amino-4-oxo-pteridine, and this bicyclic basic structure has been termed "pterin". Note that sepiapterin is not synthesized in mammals including man. Besides unconjugated pteridines, also conjugated pteridines are widely distributed in nature. Certainly the most important are folates, a group of heterocyclic compounds based on the 4-[(pteridin-6-ylmethyl lamino]benzoic acid skeleton conjugated with one or more L-glutamate units.

Correspondence to: Dr. R. Walter, Departement für Innere Mediz:n. Me丸̇zınısche Klinik B, Universitätsspital Zürich, Rämistrasse 100, CH-8091 Zürich, Te: - 1 1- -2:5-: : 1 !. Fax:-41-1-255-44-45, E-mail: roland.walter@dim.usz.ch 
abundant cellular functions in plants, bacteria, nonmammals, and mammals.

In man, tetrahydrobiopterin $\left(\mathrm{BH}_{4}\right)$ is the predominant and most important pteridine. Research on $\mathrm{BH}_{4}$ first focused on the recognized cofactor function during aromatic amino acid hydroxylation and diseases associated with inborn errors of $\mathrm{BH}_{4}$ metabolism.2 However, a century after the publication of Hopkins' short notice, it was apparent that $\mathrm{BH}_{4}$ has additional metabolic roles, and major investigators' interest turned to the relationship between these compounds and the immune system.(2) A link was made with the observation that $\mathrm{BH}_{4}$ is also essentially required for synthesis of nitric oxide (NO),(3-6) a lipid- and watersoluble gas believed to be central for host defense. $(7 ; 8)$ Concomitantly, a pivotal role of NO in the control of reviews.(2;12-23) At the turn of the millenium, however, a number of important questions remain unanswered certainly stimulating future work in this field.

\section{Materials and Methods}

\section{BIOSYNTHESIS OF BHAND ITS REGULATION}

The molecular basis of $\mathrm{BH}_{4}$ biosynthesis and regeneration has been characterized in detail. Today, stuctures and kinetics of involved enzymes are known, and corresponding human genes have been localized and cloned; for recent review see.(13)

$\mathrm{BH}_{4}$ biosynthesis and regeneration (Fig. 2)

De novo biosynthesis of $\mathrm{BH}_{4}$. De novo biosynthesis

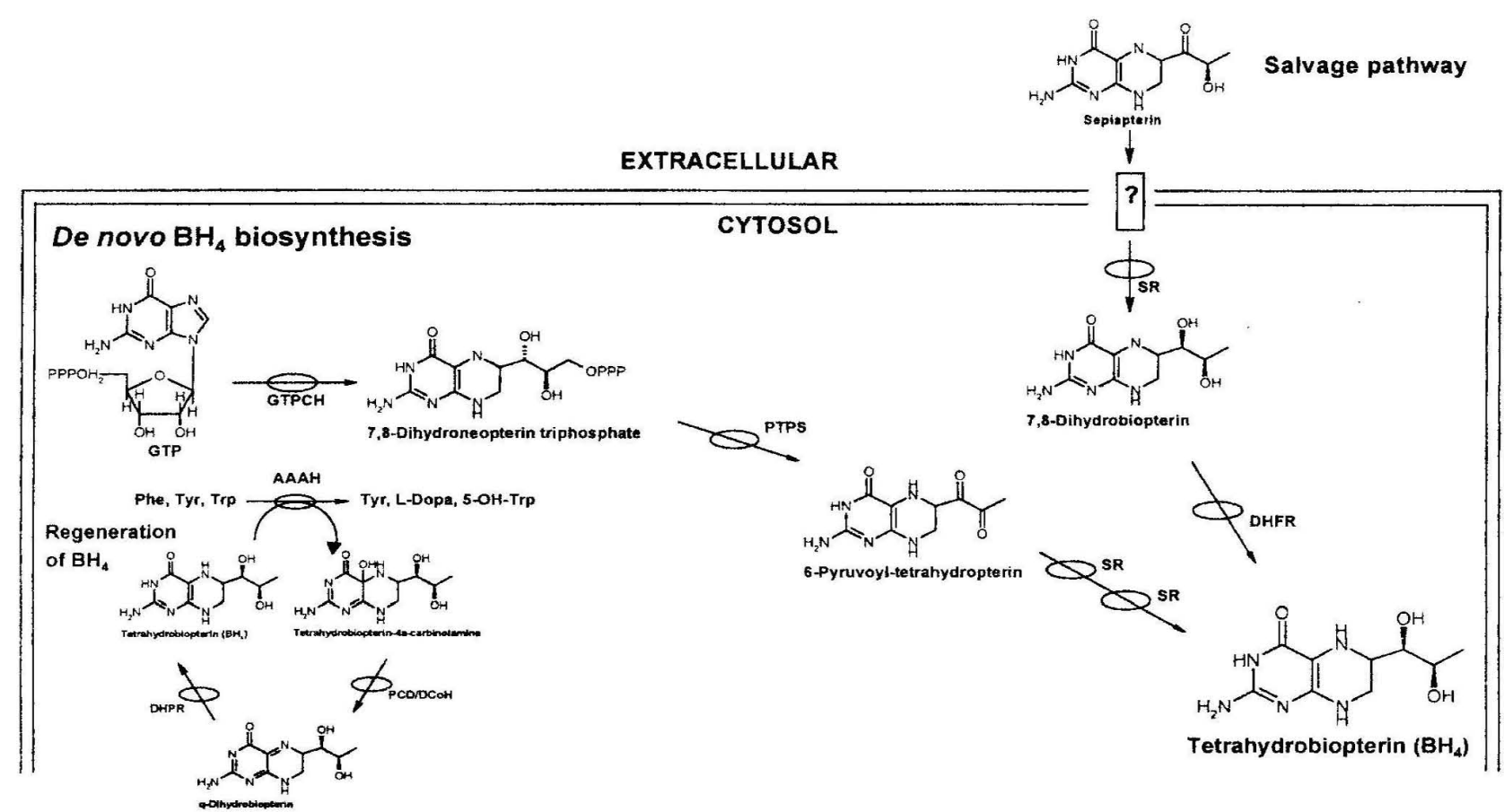

Figure 2. $\mathrm{BH}_{4}$ biosynthesis, salvage pathway, and regeneration. See text for details. De novo biosynthesis starts from GTP. Sepiapterin is not synthesized in mammalian cells, but is taken up by an yet unknown mechanism. $\mathrm{BH} 4$ oxidized during aromatic amino acid hydroxylation is recycled by a separate enzyme system. Abbreviations: AAAH, aromatic amino acid hydroxylase; DHFR, dihydrofolate reductase; DHPR, dihydropteridine reductase; GTPCH, GTP cyclohydrolase I; PCD/DCoH, pterin-4a-carbinolamine dehydratase; PTPS, 6-pyruvoyl-tetrahydropterin synthase; $\mathrm{SR}$, sepiapterin reductase.

vascular tone became established as well,(9-11) and soon data indicated that $\mathrm{BH}_{4}$ might play a critical role in the vascular system. This review will focus on that role of $\mathrm{BH}_{4}$ with emphasis on human experimental and clinical studies and will discuss the potential of $\mathrm{BH}_{4}$ as novel treatment modality for vascular disorders. Other facets of $\mathrm{BH}_{4}$ biology have been covered in recent requires three main enzymatic steps. In a first step, GTP is cleaved by GTP cyclohydrolase I (GTPCH) to yield 7,8-dihydroneopterin triphosphate in a complex catalytic mechanism resulting in several intermediates. 7,8-dihydroneopterin triphosphate is then converted to 6-pyruvoyl-5,6,7,8-tetrahydropterin (PTP) in a $\mathrm{Zn}^{2+}$ and $\mathrm{Mg}^{2+}$-dependent reaction by 6-pyruvoyl tetrahy- 
dropterin synthase (PTPS) without the need for external reducing agents. Finally, sepiapterin reductase (SR) catalyzes the reduction of the two side-chain keto groups of PTP to $\mathrm{BH}_{4}$ in a two-step reaction each requiring $\mathrm{NADPH}$ as a redox cofactor.

Regeneration of $\mathrm{BH}_{4}$. During the catalytic process of amino acid hydroxylases, $\mathrm{BH}_{4}$ is oxidized to $\mathrm{BH}_{4}-$ $4 \mathrm{a}$-carbinolamine. This compound is further dehydrated to quinoid dihydrobiopterin by pterin-4a-carbinolamine dehydratase $(\mathrm{PCD} / \mathrm{DCoH})$. Finally, the dimeric dihydropteridine reductase (DHPR) reduces quinoid dihydrobiopterin back to $\mathrm{BH}_{4}$ in a NADH-dependent reaction.

Salvage pathway. Via the pterin salvage pathway, preexisting $7,8-\mathrm{BH}_{2}$ and sepiapterin, a pteridine not naturally occuring in mammals, can be converted to $\mathrm{BH}_{4}$ Sepiapterin is converted to $7,8-\mathrm{BH}_{2}$ by SR. In the final step, $\mathrm{BH}_{4}$ is formed in a NADPH-dependent reaction by dihydrofolate reductase (DHFR).

\section{Regulation of enzyme activity involved in $\mathrm{BH}_{4}$ bio-} synthesis and regeneration

GTPCH is commonly thought to be the rate-limiting enzyme in de novo $\mathrm{BH}_{4}$ biosynthesis. Its activity is regulated at the transcriptional and post-translational level as well as via GTPCH feedback regulatory protein (GFRP) which modulates enzymatic activity by inducing an conformational change of GTPCH. $=$ gulation at the transcriptional level by pro- and anti-.tlammatory cytokines or endotoxin may be remarkable and the predominant mechanism for modulation of enzymatic activity. Compared to rodent cells, human cells have much lower PTPS activity. Therefore, 7,8-dihydroneopterin triphosphate is not efficiently converted into $\mathrm{BH}_{4}$ but is partially dephosphorylated to 7,8-dihydroneopterin by cellular phosphatases and further oxidized to neopterin. The ratelimiting effect of PTPS in human cells is reflected by accumulation of neopterin following immunostimulatory induction of GTPCH activity. Very recently, a cytokine-dependent regulation of PTPS mRNA abundance and specific activity in human vascular endothelial cells that prevents neopterin accumulation has been shown. In contrast, no significant modulation of enzymatic activity of SR has been found in vivo so far, although in vitro studies showed modification of kinetic properties following phosphorylation. Whether the enzymatic activity of PCD/DCoH, DHPR, or DHFR is regulated to a clinically important degree is unknown at present. $(13 ; 17 ; 21)$

\section{FUNCTIONS OF BH4}

$\mathrm{BH}_{4}$ as substrate of aromatic amino acid hydroxy

\section{lases}

Phenylalanine hydroxylase, tyrosine 3-hydroxylase, and tryptophan 5-hydroxylase constitute a family of enzymes which are central to normal physiology because they modulate the production of neurotransmitters and hormones such as dopamine, norepinephrine, epinephrine, serotonin, and melatonin. $(15 ; 24 ; 25)$ These homotetrameric enzymes have a strict requirement for pteridines, oxygen, and iron. $\mathrm{BH}_{4}$ has been identified as the naturally occurring cofactor, but a variety of substitutes at different positions of the pterin ring are tolerated by at least one of the monooxygenases. The pyrimidine, but not the complete pyrazine ring is required for enzymatic activity. During catalysis, one atom of oxygen from molecular oxygen is incorporated into the substrate and the other atom reduced to water. $\mathrm{BH}_{4}$, which acts as substrate rather than tightly bound cofactor, supplies both electrons required for the reduction of the second atom of water. One of the oxidation products of the catalytic reaction by all three hydroxylases is $\mathrm{BH}_{4}-4 \mathrm{a}$-carbinolamine, which is subsequently regenerated by the enzymes PCD/DCoH and DHPR.

Phenylalanine hydroxylase is allosterically regulated by phenylalanine and $\mathrm{BH}_{4}$. Whereas phenylalanine is a positive allosteric effector that converts the inactive enzyme to a catalytically active form, $\mathrm{BH}_{4}$ is a negative effector that competes with phenylalanine to form a dead-end complex with the inactive enzyme.(26;27) A further regulation of phenylalanine hydroxylase activity is achieved by phosphorylation of a serine residue resulting in a shift of the balance between the active and inactive form of the enzyme towards the active form. $\mathrm{BH}_{4}$ has been recognized to inhibit this phosphorylation.(15) All amino acid hydroxylases are inhibited by catecholamines, but only the inhibition of human tyrosine hydroxylase is competitive with respect to $\mathrm{BH}_{4}$.

\section{$\mathrm{BH}_{4}$ as cofactor for NO synthase (NOS)}

Catalysis by NOS (EC 1.14.13.39) is complex and molecular details of the reaction mechanism remain elusive; for recent comprehensive reviews see.28-34 The NOS family comprises at least three distinct homodimeric enzymes: neuronal (nNOS, NOS1), inducible (iNOS, NOS2) and endothelial (eNOS, NOS3). They have considerable similarity in catalytic function and share about $50 \%$ homology in their amino acid sequences. NOSs exhibit spectroscopic and catalytic properties strongly reminiscent of those of cytochrome $\mathrm{P} 450$ reductase and are members of the heme-thiolate family of proteins that also includes P450.

NOS catalyzes the five electron oxidation of one of 
the chemically equivalent guanidino-nitrogens of Larginine in a two-step process to finally yield L-citrulline and $\mathrm{NO}$ via $\mathrm{N}^{\text {to }}$-hydroxy-L-arginine as tightlybound intermediate. Due to the labile nature of NO, direct evidence that purified NOS directly synthesize NO has only recently been provided by electron paramagnetic resonance spectroscopy.(35)

NOS isoforms differ primarily with respect to subcellular localization, expressional regulation, posttranslational modifications, and activity modulation. nNOS contains a PDZ binding motif (found in a number of proteins implicated in ion-channel and receptor clustering, and the linking of receptors to effector enzymes. PDZ domains are protein-recognition modules) at the amino terminus that is involved in subcellular targeting of the protein, and eNOS is distinguished by the presence of myristoylation, palmitoylation, farnesylation, acetylation, and phosphorylation sites at the amino terminus that serve a similar function. Depalmitoylation of eNOS promotes the dissociation of the enzyme from its proximity to activating molecules localized in the membrane and may serve as a feedback mechansim leading to eNOS deactivation. eNOS and nNOS are considered constitutive and participate in signal cascades by synthesizing NO depending upon elevation of intracellular calcium. Main regulation of enzymatic activity occurs post-translationally. iNOS is expressed in various cell types in response to certain stimuli, such as inflammatory cytokines or bacterial cell products, and its regulation occurs mostly at the level of transcription. With tightly bound calmodulin, iNOS is fully active at basal calcium levels.

In all NOS isoforms, $\mathrm{BH}_{4}$, heme (iron protoporphyrin IX), flavin mononucleotide (FMN), and flavin adenin dinucleotide (FAD) are required as cofactors, molecular oxygen is used as cosubstrate, and NADPH donates the reducing equivalents necessary for enzymatic activity. Each monomer has two domains: a $\mathrm{N}$ terminal oxygenase domain (containing $\mathrm{BH}_{4}$ and heme) and a $\mathrm{C}$-terminal reductase domain (containing FAD and FMN) linked by a calmodulin-binding consensus sequence. All NOS isoforms dimerize through the heme domain. An unified model has been proposed to explain the enzymatic mechanisms of NOSs. Critical to NOS catalysis is the transfer of electrons from NADPH to heme. Binding of calmodulin serves to position the two domains and promotes the flow of NADPH-derived electrons from the flavins to the heme, which is thought to activate oxygen and to initiate NO synthesis. Maximum rate of NO synthesis by eNOS is severalfold slower than that of nNOS or iNOS, primarily due to low intrinsic reductase activity that limits both the delivery of electrons to the heme and overall activity of the enzyme.

$\mathrm{BH}_{4}$ is absolutely required in the catalytic reaction of NOS,(3-6) however. the exact role in the enzymatic process is still incompletely understood. It binds by hydrogen bridges with a heme propionate in a pocket situated between monomers where it interacts with residues from each subunit, and may thereby stabilize the dimeric form of the enzyme. In fact, $\mathrm{BH}_{4}$ together with the substrate L-arginine promotes the dimerization of iNOS and stabilizes the nNOS dimer; however, it does not seem to be required for the dimerization of eNOS. Modulation of NOS activity by $\mathrm{BH}_{4}$ is exclusively mediated through interactions with the heme domain. Both the pteridine cofactor and L-arginine interact with the same heme propionate which explains the interplay between $\mathrm{BH}_{4}$ and substrate binding. Indeed, allosteric effects of $\mathrm{BH}_{4}$ on NOS have long been described. $\mathrm{BH}_{4}$ triggers the conversion of the inactive low-spin to the active high-spin conformation of the enzyme, and $\mathrm{BH}_{4}$ interacts with $\mathrm{L}$-arginine by positive cooperativity. An unusual aspect of $\mathrm{BH}_{4}$ binding is that two identical but highly anticooperative binding sites for $\mathrm{BH}_{4}$ have been found for $\mathrm{nNOS}$ and iNOS. With binding of a first $\mathrm{BH}_{4}$ to the NOS dimer, one $\mathrm{L}$-arginine is tightly bound, and this greatly weakens the affinity of the second $\mathrm{BH}_{4}$ and $\mathrm{L}$-arginine binding sites in the NOS dimer for both, $\mathrm{BH}_{4}$ and L-arginine, respectively. It is therefore possible that NOS could contain only one $\mathrm{BH}_{4}$ per dimer in some biological settings. For human nNOS, dual allosteric interactions between $\mathrm{BH}_{4}$ binding site and L-arginine-binding site have been confirmed. $\mathrm{BH}_{4}$ binding not only increases enzyme activity but also decreases the apparent $\mathrm{Km}$ for L-arginine, and, conversely, L-arginine activates human nNOS by allosterically modulating/increasing the affinity for binding of $\mathrm{BH}_{4}$. The 1,2-dihydroxypropyl side chain at the 6-position has been suggested to promote cooperativity of $\mathrm{BH}_{4}$.(36)

Recent data indicate a redox-active role of $\mathrm{BH}_{4}$ in the NOS reaction. Experiments with $\mathrm{BH}_{4}$-free NOS indirectly implicate the reduced pteridine cofactor in the first step of the reaction. Together with the newly recognized participation of nonheme ferrous iron in the reaction, the current information raise the possibility that the pteridine may act in this step in an analogous fashion to that characterized for the amino acid hydroxylases. Furthermore, it has been established that $\mathrm{BH}_{4}$ promotes the transition of the heme group from low to high spin-state thereby facilitating electron transfer from the flavoprotein domain resulting in the reduction of heme-iron from ferric to the ferrous form, which is required for the conversion of $\mathrm{L}$-arginine to $\mathrm{N}^{\prime \prime \prime}$-hydroxy-L-arginine. Critical to all mechanistic 
considerations is the formation of the ferrous-dioxygen NOS complex during the second step of NOS catalysis. $\mathrm{BH}_{4}$ decreases the lifetime of this complex (as shown for nNOS) and may therefore influence the course of the reaction by affecting electron transfer. Recent low temperature experiments suggested that $\mathrm{BH}_{4}$ may donate an electron required for activation of the ferrous dioxygen complex thereby generating a pteridine radical, which is rapidly reduced intraenzymically thereafter as part of the NOS catalytic cycle.

Enzyme-generated NO can bind to the NOS heme and influence subsequent catalysis in a reversible manner as the NO-bound form is inactive ("NO feedback inhibition"). Both iNOS and nNOS intrinsically form heme-NO complexes during NO synthesis, and a majority of enzyme may partition into the inactive form due to insufficiently slow dissociation of NO from NOS. $\mathrm{BH}_{4}$ has been shown to attenuate NO feedback inhibition thereby stimulating enzymatic activity. Possible mechanisms may include removal of NO by reaction with superoxide formed in the course of $\mathrm{BH}_{4}$ autoxidation, and destabilization of the heme-NO complex. In contrast, little or no NO complex is formed during NO generation from eNOS, most probably due to slow electron transfer between flavins and heme resulting in a low NO concentration. These findings indicate that NO feedback inhibition has a minimal role in eNOS catalysis.(37)

Recent data suggest that intracellular $\mathrm{BH}_{4}$ availability may regulate iNOS mRNA and protein expression. This effect appears to be mediated, at least in part, by an increase in iNOS mRNA stability. $(38 ; 39)$

An important aspect of NOS catalysis is the formation of oxygen-derived free radicals as a general feature of all NOSs which has been studied over the recent years in detail by use of electron paramagnetic resonance spin-trapping experiments with purified NOS. Evidence indicates that $\mathrm{BH}_{4}$ plays a critical role not only in increasing the rate of NO generation but also in controlling the formation of superoxide and hydrogen peroxide by NOS.

Besides synthesizing NO, nNOS can catalyze superoxide formation at low levels of L-arginine in a calcium/calmodulin-dependent process.(35;40-42) In vitro studies using nNOS transfected cells showed that NO production declined with L-arginine depletion whereas the production of superoxide increased, and this switch of NOS from the production of NO to superoxide crucially depended on intracellular levels of L-arginine.(43) The source of superoxide remains unclear. Some investigators suggested the formation of superoxide at the oxygenase domain of nNOS, whereas others implicated the reductase domain of $\mathrm{nNOS}$, or both.(44)
L-arginine controls the generation of superoxide by decreasing the rate of NADPH consumption.(44) In assays with purified nNOS protein, superoxide may also be generated by the reductive reaction of high concentrations of FAD with NADPH.(35) In addition, in the presence of a redox-cycling compound such as FMN, nNOS increases the generation of superoxide in a calcium/calmodulin-independent manner.(44)

Occupation of the L-arginine binding site may stabilize the ferric superoxide complex,(45) and the prevention of dissociation of this complex is proposed to decrease the generation of superoxide both from the oxygenase and reductase domains of nNOS.(44)

Pteridine-free purified nNOS generates superoxide from the reductase and the oxygenase domain by a calcium/calmodulin-dependent mechanism. Generation of superoxide by this pathway in tightly controlled by $\mathrm{BH}_{4}$, possibly by promoting the formation of hemeperoxo species. In the presence of both L-arginine and $\mathrm{BH}_{4}$, the formation of the oxoferryl will occur thereby facilitating the oxidation of $\mathrm{L}$-arginine to generate $\mathrm{N}$ ?hydroxy-L-arginine $44 \mathrm{BH}_{4}$ and $\mathrm{L}$-arginine also stabilize dimeric nNOS during catalysis and markedly inhibit monomerization, thereby reducing enzyme inactivation induced by the generation of reactive oxygen species. It has been proposed that $\mathrm{BH}_{4}$ may directly scavenge excessively generated superoxide and subsequently degrade to yet unknown products in situations when L-arginine levels are limiting.(36)

Hydrogen peroxide may be formed by nNOS by two different mechanisms depending on the availability of $\mathrm{BH}_{4}$. At low $\mathrm{BH}_{4}$ concentrations, nNOS will generate only superoxide that, by dismutation, will produce hydrogen peroxide and oxygen. In the presence of $\mathrm{BH}_{4}$, however, no superoxide will be formed, and the enzyme will generate hydrogen peroxide by a mechanism involving a two-electron reduction of oxygen.(44) $\mathrm{BH}_{4}$ decreases the generation of hydrogen peroxide by nNOS while increasing L-citrulline formation. $(41 ; 46)$

Superoxide and NO synthesis can also occur simultaneously within iNOS in experiments with purified protein,(47) and in L-arginine depleted macrophages iNOS has been shown to generate peroxynitrite,(48) a powerful oxidant with a relatively long half-life that is formed at a diffusion-limited rate from NO and superoxide.(49) Superoxide generation mainly occurs at the flavin-binding sites of the reductase domain.(47) In experiments using $\mathrm{BH}_{4}$-free iNOS expressed in E. coli, $\mathrm{BH}_{4}$ shifted iNOS from a superoxide producing to a peroxynitrite producing enzyme in the absence of superoxide dismutase (SOD, EC 1.15.1.1); only the addition of SOD resulted in a detectable NO signal.(50) 
iNOS and nNOS exhibit very different L-argininedependent inhibition of superoxide generation. Inhibition of superoxide generation from iNOS was only seen at high L-arginine concentrations, whereas low L-arginine levels completely block superoxide formation from nNOS. $(41 ; 47)$ The reason for this difference is not yet clear. However, it has been concluded that because of relative high cytosolic levels of L-arginine, superoxide generation would rarely occur with nNOS, whereas the simultaneous NO and superoxide generation from iNOS may be beneficial since these two free radicals will interact to form the more potent toxic oxidant peroxynitrite which will prevent feedback inhibition of iNOS and may enhance killing activity by iNOS.(47)

Superoxide can be generated by eNOS in a calci$\mathrm{um} /$ calmodulin-dependent manner from the dissociation of a transient heme ferrous-dioxygen complex in the oxygenase domain of eNOS. $\mathrm{BH}_{4}$ dose-dependently decreases superoxide levels both by coupling Larginine oxidation to NADPH consumption and by direct scavenging properties. In contrast to the effect of $\mathrm{BH}_{4}$, L-arginine does not control superoxide generation and does not interfere with the release of superoxide from heme iron. Therefore, eNOS mediated superoxide generation is triggered and controlled by decreased availability of $\mathrm{BH}_{4}$ rather than L-arginine leading to a switch of eNOS from NO to superoxide production in states of $\mathrm{BH}_{4}$ depletion. $(51 ; 52)$ Most interestingly, preliminary data indicate that the ratio of $\mathrm{BH}_{4}$ to 7,8-BH2 may control superoxide generation as $\mathrm{BH}_{4}$-oxidized derivatives compete with $\mathrm{BH}_{4}$ for the $\mathrm{BH}_{4}$-binding site at the oxygenase domain of eNOS resulting in uncoupling and increased superoxide production.(53)

NO interacts with various intracellular molecular sites within both the generating and target cell, a distinct NO receptor does obviously not exist. The biology of NO signaling has recently been reviewed in detail.(54) Direct effects of NO include interactions with transition metals leading to formation of stable nitrosyl complexes via covalent reactions between NO and metal ions, redox reactions between $\mathrm{NO}$ and metal ions, and NO binding to iron-sulfur clusters in proteins. Overall, the interaction of NO with the heme component of soluble guanylate cyclase with subsequent stimulation of enzymatic conversion of GTP to cyclic guanosine 3',5'-monophosphate (cGMP) constitutes the major pathway of NO signaling. Other direct effects of NO include reactions with free radicals. In states of sustained and enhanced NO flux, reactive nitrogen species are formed, and indirect effects of NO are consequences of S-nitrosation reactions. Most, if not all of these indirect effects of NO are dependent on reactions with oxygen and superoxide, giving rise to dinitrogen trioxide and peroxynitrite.(54) Some of these direct and indirect effects of NO in the vasculature are modulated by $\mathrm{BH}_{4}$ and are discussed below.

\section{$\mathrm{BH}_{4}$ as cofactor for other enzymes}

$\mathrm{BH}_{4}$ is involved in the reactions of at least three other enzymes. The reduced pteridine is required by the glyceryl-ether mono-oxygenase (EC 1.14.16.5) for hydroxylation of the a-carbon atom of the lipid carbon chain of glyceryl ether to form a-hydroxyalkyl glycerol.(55) Furthermore, the dopamine-b-hydroxylase (EC 1.14.17.1) in the pathway from dopamine to noradrenalin also depends on $\mathrm{BH}_{4}$.(56) Finally, $\mathrm{BH}_{4}$ can directly control tyrosinase (EC 1.14.18.1) activity, the key enzyme in melanin biosynthesis in melanocytes, by uncompetitive inhibition via a specific binding domain on the enzyme.(57) $\mathrm{BH}_{4}$ has also been suggested to participate as physiological coenzyme in the catalysis of indoleamine 2,3-dioxygenase (EC $1.13 .11 .42),(58 ; 59)$ however, these findings have been questioned by others.(2)

\section{Other functions of $\mathrm{BH}_{4}$}

As mentioned above, the first cellular function of $\mathrm{BH}_{4}$ recognized was the promotion of growth for the protozoon Crithidia fasciculata;(60) microbiological assays using the nutritional requirement of this organism for the L-erythro configuration of biopterin have been developed for quantification of this pterin in diferent body fluids and tissues and utilized for some time; however, they needed a period of several days to obtain accurate results, and they were finally replaced by novel and even more sensitive detection techniques, e.g. radioimmunoassays, gas chromatography mass spectrometry, or high-performance liquid chromatography. $(61 ; 62)$

In addition to its cofactor role for NOSs and aromatic amino acid hydroxylases, other functions of $\mathrm{BH}_{4}$ in the nervous system have been suggested. These include a role as a neurotransmitter-releasing factor, first demonstrated for dopamine in the rat striatum (.63) This effect may be mediated by activation of neuronal calcium channels via cAMP-protein kinase A pathway independent of cofactor activity, for recent review on the role of $\mathrm{BH}_{4}$ in the nervous system, see reference (14).

It has long been proposed that $\mathrm{BH}_{4}$ may be involved in cell proliferation, cell differentiation, and cell-mediated immunity. Such effects have been independently observed by several groups, however, the part of $\mathrm{BH}_{4}$ is complex and far from being clear. $(2 ; 64)$ Concerning the vascular system, $\mathrm{BH}_{4}$ has been shown to stimulate in vitro angiogenesis in bovine aortic endothelial cells 
by yet unclear mechanisms.(65) Nevertheless, it is of note that proliferative effects of several growth factors seem to depend on an obligatory elevation of intracellular $\mathrm{BH}_{4}$ levels. This has first been shown for epidermal growth factor and nerve growth factor on the proliferation of rat phaeochromocytoma PC12 cells.(66) $\mathrm{BH}_{4}$-involvement in cell cycle-dependent events by affecting $\mathrm{c}-\mathrm{Myc}$ expression has been described very recently.(67) Furthermore, a critical role of $\mathrm{BH}_{4}$ in the signaling cascade of vascular endothelial growth factor (VEGF) has been suggested (see below for details).

Of major importance for the effect of $\mathrm{BH}_{4}$ in the vascular system, especially under pathophysiological conditions, is the strong antioxidative activity of reduced pterins; 18 this unspecific function of $\mathrm{BH}_{4}$ will be discussed in a later section of this review.

A modulatory role for $\mathrm{BH}_{4}$ in the expression of of cyclooxygenase 2 has been shown for human mesangial cells. In these cells, supplementation with $\mathrm{BH}_{4}$ potentiated cytokine-induced expression of cyclooxygenase 2 in an obviously NO-independent manner. If confirmed, these data corroborate the role of $\mathrm{BH}_{4}$ as an important cellular mediator molecule in response to inflammatory stimuli.(68)

Finally, recent studies indicated an important role for $\mathrm{BH}_{4}$ in regulation of human melanogenesis, for which tyrosinase (EC 1.14.18.1) that catalyzes the oxidation of L-tyrosine to the melanin precursor Ldopaquinone is the key enzyme. The rate of de novo melanin synthesis depends on supply of the substrate L-tyrosine or direct tyrosinase inhibition/activation. The $\mathrm{BH}_{4}$ pathway is induced by UVB irradiation in relation to the degree of pigmentation, resulting in enhanced phenylalanine hydroxylase activity which may in turn supply L-tyrosine within melanocytes. In addition, $\mathrm{BH}_{4}$ (but not oxidized forms) directly regulates tyrosinase activity by uncompetitive inhibition. The $\mathrm{BH}_{4} /$ tyrosinase inhibitor complex can be activated either by UVB photooxidation of $\mathrm{BH}_{4}$, or by specific complexation with the 13 amino acid peptide amelanocyte stimulating hormone (a-MSH). a-MSH, which is present in melanocytes, forms a specific and stable 1:1 complex with $\mathrm{BH}_{4}$, thereby protecting the pteridine from photo-oxidation. Low levels of $\alpha$-MSH activate phenylalanine hydroxylase, probably by removal of $\mathrm{BH}_{4}$ from inactive tetramers of phenylalanine hydroxylase to yield active dimers. Since $\alpha-\mathrm{MSH}$ levels are increased after LTB exposure, $\alpha-\mathrm{MSH}$ has been postulated as a chaperone for $\mathrm{BH}:$ in the human epidermis. The redox state of $\mathrm{BH}$ : may influence not only pigmentation but also melano:te survival and the process of keratinocyte differertation. Pteridines are the principal molecules causirg the :luorescence of depigmented skin used as a diagnosti 100 : in the depigmentation disorder vitiligo, and major disturbances in $\mathrm{BH}_{4}$ metabolism and dependent enzymes have been found in vitiligo, eventually induced by epidermal $\mathrm{H}_{2} \mathrm{O}_{2}$ accumulation, but also in the HermanskyPudlak-Syndrome, a rare depigmentation disorder with autosomal recessive inheritance; however, the exact mechansims underlying these disturbances remain uncompletely understood at present.(69-73)

\section{$B_{4}$ AND THE VASCULAR SYSTEM}

Recent years established the importance of $\mathrm{BH}_{4}$ in the vascular system in health and disease. Most effects were linked to the L-arginine-NO-cGMP signaling system, and the vascular endothelium, a dynamic organ with vital secretory, metabolic, immunologic, and vasoregulative functions, $(74 ; 75)$ revealed to be central for $\mathrm{BH}_{4}$ as a source and functional target of the pteridine. Soon after the discovery of an endotheliumderived relaxing factor (EDRF), (9) it was recognized that EDRF has identical properties as NO, a molecule known at that time to cause smooth muscle relaxation,(76) and EDRF was subsequently proposed to be either NO or a very labile nitroso compound readily releasing NO. $(10 ; 11 ; 77)$ The ubiquity of the NO molecule has rapidly become clear, and it is now seen as a key mammalian metabolite for signaling in biological systems.(54;78-83)

NO maintains basal vessel tone by relaxing vascular smooth muscle cells, modulates vascular resistance in response to neurohormonal agents or physical forces, inhibits interactions between blood cells and vessel wall, is involved in the maintenance of vascular integrity, and influences proliferation and migration of smooth muscle cells. $(74 ; 84-86)$ In the physiologic state, vascular endothelial cells of different species including man (87-90) constitutively express eNOS protein. Endothelium-derived NO diffuses rapidly into subjacent vascular smooth muscle, where it binds to the heme iron complex of soluble guanylate cyclase and stimulates the production of cGMP and relaxation of vascular smooth muscle.(54;91) Attention has recently focused on the regulatory properties of $\mathrm{BH}_{4}$ on eNOS activity.

\section{$\mathrm{BH}_{4}$ and the physiologic function of the vascular system}

Endothelial cells. Human vascular endothelial cells express all enzymes for de novo $\mathrm{BH}_{4}$ biosynthesis.(88;92-94) Cellular $\mathrm{BH}_{4}$ turnover may be very rapid, as treatment with inhibitors of $\mathrm{BH}_{4}$ biosynthesis deplete intracellular $\mathrm{BH}_{4}$ levels within a few hours. $(92 ; 95)$ Cultured endothelial cells constitutively express GTPCH activity and synthesize small amounts 
:f $\mathrm{BH}_{4}$, but prolonged culturing seems to cause a Jecline of intracellular $\mathrm{BH}_{4}$ levels and a disappearance of GTPCH activity.(88) Human endothelial cells secrete the pteridine, $(93 ; 96)$ possibly vectorially into the basal direction.(97) Recently, evidence has been provided that human endothelial cells secrete not the fully reduced cofactor, but considerable amounts of 7,8- $\mathrm{BH}_{2}$ and some biopterin.(96) This finding needs confirmation and is somewhat surprising since in all mammalian tissues that have been examined in vivo
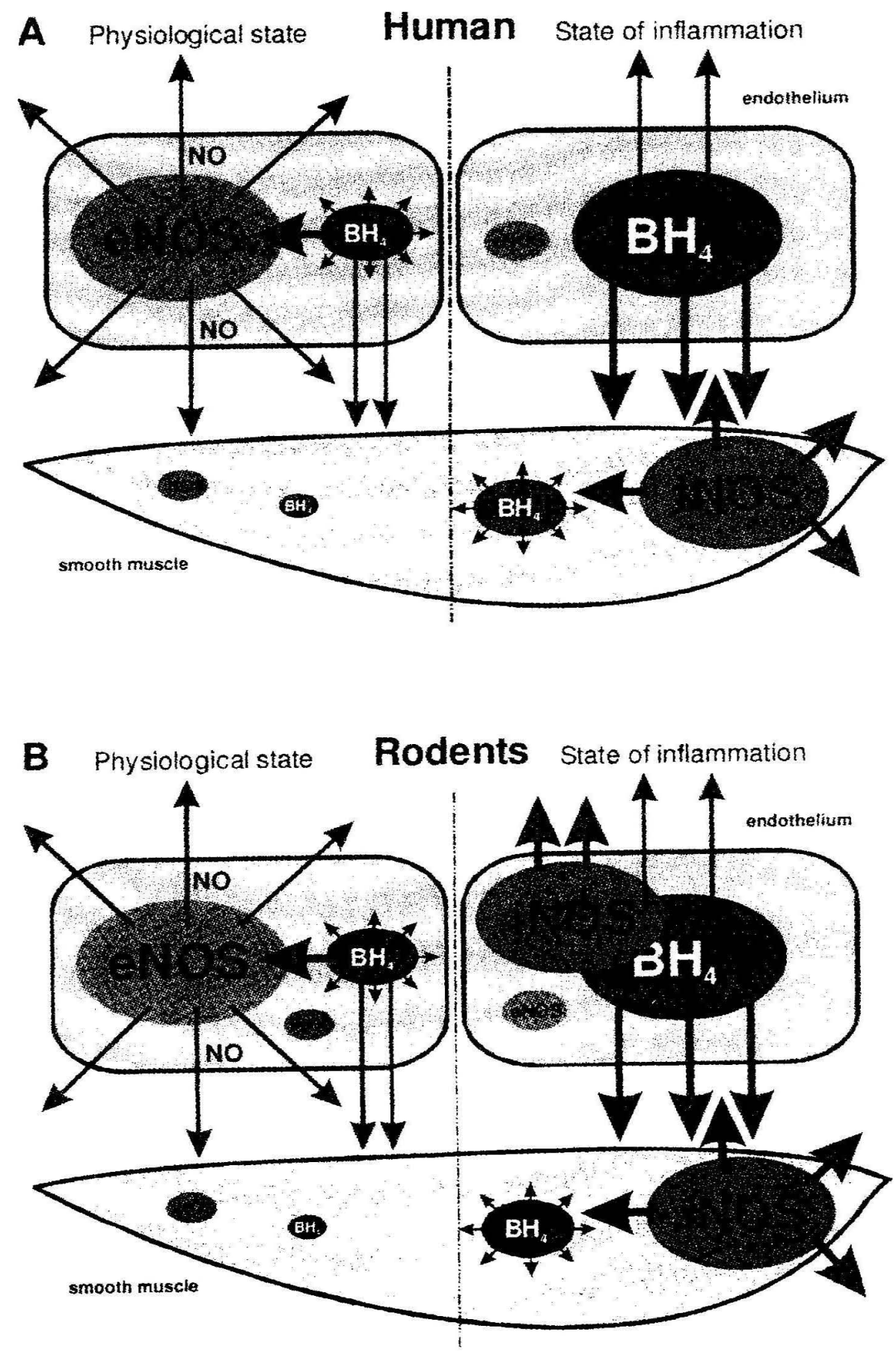

Figure 3, "Switch model". Regulation of NOS and BH4 synthetic activity under normal and inflammatory conditions in human (A) and rodents (B). See text for details. 
$85-100 \%$ of biopterin present is in the tetrahydro form. $(98 ; 99)$

The signal transduction mechanism for and regulation of gene expression and the reason for the decrease of intracellular $\mathrm{BH}_{4}$ during culture is unknown at present. However, GTPCH gene expression may be regulated by calcium influx,(100) and it is tempting to speculate that such a mechanism might be involved.

In cultured endothelial cells, exogenous sepiapterin increases intracellular $\mathrm{BH}_{4}$. The GTPCH inhibitor 2,4diamino-6-hydroxypyrimidine (DAHP) significantly reduces $\mathrm{BH}_{4}$ levels within these cells which can be restored by sepiapterin. $(92 ; 95)$ These data show restoration of intracellular $\mathrm{BH}_{4}$ via activation of the salvage pathway demonstrating that precursors of $\mathrm{BH}_{4}$, such as sepiapterin, can be used as pharmacological tools to augment the pool of functional pteridine cofactor in vitro. However, the relative importance of this pathway in vivo remains unclear.

The bioavailability of $\mathrm{BH}_{4}$ is pivotal for endothelial function, and intracellular $\mathrm{BH}_{4}$ levels potentially regulate endothelial NO synthesis and vascular tone $(88 ; 95 ; 101 ; 102)$. eNOS activity in freshly isolated or cultured human endothelial cells is limited by intracellular $\mathrm{BH}_{4} .(88 ; 96)$ Pretreatment of cultured cells with pro-inflammatory cytokines also largely increases eNOS activity and histamine-stimulated NO production, mainly due to increased GTPCH activity and subsequent elevated $\mathrm{BH}_{4}$ levels.(88) In contrast, inhibition of $\mathrm{BH}_{4}$ synthesis by DAHP reduces endothelial NO production. $(92 ; 95 ; 96)$

Smooth muscle cells. Functional de novo $\mathrm{BH}_{4}$ biosynthetic and salvage pathways have also been found in human vascular smooth muscle cells. $(103 ; 104)$ However, GTPCH is barely expressed in cultured unstimulated human umbilical vein smooth muscle cells, only trace amounts of the pteridine are measured intracellularly, and no substantial amounts of $\mathrm{BH} 4$ are secreted.103 Since in cultured human smooth muscle cells neither iNOS nor eNOS mRNA is detected in the resting state, $39 ; 87$ it can be assumed that $\mathrm{BH}_{4}$ should have no direct NO-mediated relaxing effect on smooth muscle cells under physiologic conditions. This is corroborated by results from numerous studies which failed to demonstrate an influence of $\mathrm{BH}_{4}$ on endothelium-independent relaxation. In addition, the availability of $\mathrm{BH}_{4}$ obviously does not affect the reactivity of smooth muscle cells to NO.(19) Taken together, these data indicate that under physiological conditions in man, both $\mathrm{NO}$ and $\mathrm{BH}_{4}$ production solely take place in the vascular endothelium but not in the underlying smooth muscle (Fig. 3A, left side).

Isolated vessels in vitro and in vivo experiments. $\mathrm{BH}_{4}$ is present in intact arteries and veins, and about
$60 \%$ of total $\mathrm{BH}_{4}$ is located within endothelial cells.(102) This may however, not necessarily reflect true rates of production since endothelial cells secrete $\mathrm{BH}_{4}$ that may be taken up by other cells. Indeed, rat smooth muscle cells readily take up $\mathrm{BH}_{4}$ and sepiapterin, $(39 ; 105 ; 106)$ and sepiapterin is also taken up by human vascular smooth muscle cells.(104) In line with these data are gene transfer experiments demonstrating that GTPCH activity and resulting $\mathrm{BH}_{4}$ does not have to coexist in the same cell for the synthesized $\mathrm{BH}_{4}$ to support iNOS activity.(107) Although formal proof for $\mathrm{BH}_{4}$ uptake into human smooth muscle cells is lacking at the moment, it is conceivable to believe that $\mathrm{BH}_{4}$ produced endogenously in vascular endothelial cells or elsewhere in the human body, traffics into smooth muscle cells of the vasculature.

Extending experiments on cultured cells, enhancement of endothelial $\mathrm{NO}$ synthesis by exogenous $\mathrm{BH}_{4}$ could also be demonstrated in isolated vessels in vitro,(101) and relaxation was accompanied by dosedependent increases of intracellular cGMP levels (108)The effect of $\mathrm{BH}_{4}$ on vessels in vitro seem to critically depend on experimental conditions, and additional $\mathrm{BH}_{4}$ may even cause vessel contraction. $(102 ; 109)$ a result that has been explained by autoxidation of $\mathrm{BH}_{4}$ and generation of superoxide anions.19 This hypothesis was corroborated by the observation that superoxide dismutase (SOD) enhanced endothelium-dependent relaxation in arteries with increased intracellular $\mathrm{BH}_{4}$ levels.(102)

In vivo data suggest that under physiologic conditions levels of endogenous $\mathrm{BH}_{4}$ are nearly saturating and barely a limiting factor for optimal or near optimal endothelial eNOS activity,(110-114) and only high doses of $\mathrm{BH}_{4}$ may induce a marked local vasodilation. $(97 ; 115)$ In contrast to the requirement of rather high local $\mathrm{BH}_{4}$ levels for vasodilating effects on the systemic circulation in healthy human subjects, myocardial blood flow may be increased at doses of $\mathrm{BH}_{4}$ at which systemic hemodynamics are not affected suggesting that different human circuits may be differently susceptible to exogenous $\mathrm{BH}_{4}$.(116)

Endothelium-dependent relaxation mediated by $\mathrm{BH}_{4}$ under inflammatory conditions: proposal of the "switch" model

The expression of eNOS has traditionally been considered constitutive, but a multitude of regulating factors have been recognized. $(86 ; 117 ; 118)$ Pro- and antiinflammatory cytokines are probably of pivotal importance for the regulation of vascular tone under inflammatory conditions. Pro-inflammatory cytokines and endotoxin may transiently increase NO synthesis in human vascular endothelial cells $(88 ; 92 ; 119)$ by indi- 
rect regulation that includes enhanced synthesis of $\mathrm{BH}_{4 .}$ (92) Nevertheless, there is increasing evidence that eNOS is downregulated under inflammatory conditions. Inflammatory stimuli decrease NO production and reduce eNOS protein and $\mathrm{mRNA}$ levels in cultured endothelial cells, $(87-89 ; 120-123)$ at least partially due to enhanced degradation rates of eNOS transcripts.(124-126) In contrast, anti-inflammatory cytokines may induce eNOS mRNA, protein, and activity.(127)

Inflammatory stimuli simultaneously induce the expression of iNOS mRNA and subsequent "high-output" NO production. Vascular smooth muscle cells from different species, including man, express iNOS mRNA and functional protein upon stimulation. Activation of the L-arginine-NO pathway and iNOS expression has been confirmed in human septic shock (128), although it has sometimes proved difficult to demonstrate a clear role for iNOS in human vessels in vivo for cytokine-induced vasodilation and a number of human experiments failed to show the consistent presence of iNOS under conditions in which this NOS isoform is readily induced in animals.(129) Important to note that whereas expression of iNOS has also been found in murine, swine, bovine, and rat endothelial cells, $(123 ; 130-134)$ human endothelial cells obviously express only eNOS but do not contain any iNOS.(8890) Furthermore, no eNOS mRNA is detected neither under unstimulated nor under inflammatory conditions within human vascular smooth muscle cells. $(39 ; 87)$

Culture of vascular cells with inflammatory stimuli increases expression of GTPCH, its enzymatic activity, and subsequently augments intracellular $\mathrm{BH}_{4}$ levels, $(88 ; 92 ; 105 ; 135)$ whereas deactivating cytokines efficiently suppress $\mathrm{BH}_{4}$ generation.(93) The increase in cellular $\mathrm{BH}_{4}$ is mainly due to induction of de novo biosynthesis rather than via the salvage pathway using pre-existing dihydropterins. $(94 ; 136)$ In human vascular endothelial cells, most of the newly synthesized pteridine is secreted into the culture supernatant.(93) $\mathrm{BH}_{4}$ biosynthesis is essentially required for induction of NOS activity, $(38 ; 105 ; 137 ; 138)$ and inhibition of $\mathrm{BH}_{4}$ biosynthesis reduces iNOS activity in cytokinestimulated cells. $(38 ; 105 ; 138-141)$ Although expression of GTPCH and iNOS appears to be regulated coordinately $(135 ; 142-144)$ and $\mathrm{BH}_{4}$ contributes to enhanced iNOS expression through stabilization of iNOS mRNA, $(38 ; 39)$ intrinsic $\mathrm{BH}_{4}$ availability is a limiting factor for iNOS activity in many cell types including rat smooth muscle cells, $(38 ; 105 ; 106$; $137 ; 139 ; 145 ; 146)$ rendering NO production of these cells susceptible to modulation of intracellular $\mathrm{BH}_{4}$ levels. Treatment with inflammatory stimuli also enhances transcription of GTPCH mRNA and increas- es intracellular $\mathrm{BH}_{4}$ levels in human umbilical smooth muscle cells, and small amounts of $\mathrm{BH}_{4}$ are also secreted in the culture supernatant;(103) however it remains to be demonstrated whether $\mathrm{BH}_{4}$ is also limiting for NO synthesis in human smooth muscle cells.

Activation of $\mathrm{BH}_{4}$ biosynthesis has been confirmed in animal experimental sepsis, $(144 ; 147-150)$ and in some models biopterin apparently represents a more appropriate biochemical marker of septic shock than the determination of plasma NOx levels.(151) The regulation of $\mathrm{BH}_{4}$ biosynthesis upon inflammatory stimuli in human vessels in vivo remains elusive, however, the induction of GTPCH in human veins challenged with cytokines has recently been confirmed.(115)

Taken the current knowledge together, a "switch" model is proposed to summerize changes of regulation of $\mathrm{NO}$ and $\mathrm{BH}_{4}$ synthesis between physiologic and inflammatory conditions in the human vasculature (Fig. 3A). Although stimulatory cytokines may increase NO synthesis in human vascular endothelial cells, the concomitant dramatic decrease of eNOS mRNA makes this increase only transient, and a significantly reduced NO production is expected to occur after a certain time of ongoing inflammation. Thus, it must be concluded that NO could only account as an EDRF during short term but not during long term inflammation in man. Whereas eNOS mRNA and protein is downregulated, iNOS is induced, e.g. NO production switches and is no longer associated with eNOS but iNOS activity. Furthermore, the compartment responsible for NO production switches as well. Whereas eNOS is located in the vascular endothelium, iNOS is expressed in underlying smooth muscle cells. In contrast, the vascular endothelium continues to produce and secrete $\mathrm{BH}_{4}$, and much higher amounts of $\mathrm{BH}_{4}$ are secreted under inflammatory conditions. Although $\mathrm{BH}_{4}$ synthesis is also induced in underlying smooth muscle cells upon inflammatory stimulation, these cells depend on exogenous $\mathrm{BH}_{4}$ for full iNOS activity and readily take up the pteridine cofactor. $\mathrm{BH}_{4}$ could therefore account as an EDRF during prolonged inflammation marking the third switch, i.e. the switch from $\mathrm{NO}$ as an EDRF under physiological to $\mathrm{BH}_{4}$ as an EDRF under inflammatory conditions. As emphasized, species differences exist with respect to iNOS expression in vascular endothelial cells. Thus, the switch from exclusive endothelial to exclusive smooth muscle NO production is not generally valid, and in other species (e.g. in rat and mouse) iNOS may be expressed in both the endothelial and the smooth muscle compartment. As a result, both $\mathrm{NO}$ and $\mathrm{BH}_{4}$ may coexist as EDRFs in these species under inflammatory conditions (Fig. 3B). 
Experimental evidence for the switch model has been obtained both in vitro $(87 ; 123)$ as well as in vivo in rats. 152 In healthy subjects in vivo, the early phase of inflammatory vasodilation may be mediated by eNOS activation due to increased amounts of $\mathrm{BH}_{4}$, (115) but the question whether the switch from eNOS to iNOS takes place in later stages remains open.

Besides the induction of $\mathrm{BH}_{4}$ biosynthesis in animal models of sepsis experimental data also indicate that inhibition of $\mathrm{BH}_{4}$ metabolism or removal by hemoperfusion may prevent hemodynamic alterations suggesting the potential as novel therapeutic strategy against morbidity and mortality of septic shock.(153-156).

Oxidative stress: interplay of oxygen-derived free radicals with $\mathrm{NO}$ and $\mathrm{BH}_{4}$

Endothelial functions are disrupted by a wide variety of perturbations. "Endothelial dysfunction" is believed to be an early event and important contributor in the etiology of several human vascular diseases, e.g. atherosclerosis, ischemia/reperfusion injury, and heart failure. $(74 ; 84)$ Besides loss of endothelial production and/or bioavailability of NO, a common denominator in these disorders comprises increased production of reactive oxygen intermediates ( $\mathrm{ROI}$ ), a class of molecules that includes superoxide anions, hydrogen peroxide, and hydroxyl radicals. Under certain conditions, production of ROI may outweigh endogenous antioxidant defense mechanisms, referred to as oxidative stress, and participate in the pathogenesis of cardiovascular disorders.(157) Many enzymatic systems are potential sources of ROI, which in turn can interact with vascular signaling systems and potentially oxidize any molecule in a cell, causing DNA nicking and disruption, lipid peroxidation, and protein cross-linking and degradation.(157-159)

The level of intracellular $\mathrm{BH}_{4}$ is critical for the degree of ROI production by eNOS. Activation of purified eNOS in the presence of suboptimal levels of $\mathrm{BH}_{4}$ results in uncoupling of oxygen reduction and arginine oxidation as well as generation of increased amounts of ROI, $(51 ; 52)$ a finding that was confirmed in vitro and in vivo.(160-163) The $\mathrm{BH}_{4} / 7,8-\mathrm{BH} 2$ ratio seems to control superoxide generation by eNOS as oxidized derivatives of $\mathrm{BH}_{4}$ compete for binding and lead to enhanced ROI production implicating the redox state of the cofactor to be of central importance.(53) Therefore, decreased availability of $\mathrm{BH}_{4}$ may cause a shift in the balance between the production of protective NO and toxic ROI and contribute to endothelial dysfunction and oxidative vascular injury. Interestingly, hydrogen peroxide itself may become a mediator of endothelium-dependent relaxations in states of $\mathrm{BH}_{4}$ deficiency in vitro,(160) whereas super- oxide causes endothelium-dependent contractions mediated in part by chemical inactivation of NO (see below).

Oxidative stress may contribute to impaired endothelium-dependent vasodilation through accelerated NO degradation. Superoxide reacts with NO in a nearly diffusion limited reaction yielding peroxynitrite at a reaction rate more than 3 times faster than that for superoxide with SOD.(164) Since the interaction of superoxide anions with NO is extremely rapid, this may even occur under physiologic conditions, and NO availability may become markedly reduced by superoxide anions and probably other radicals.

Peroxynitrite, a powerful oxidant with a relatively long half-life, is considered a primary reactive nitrogen species responsible for deletorious effects of NO. It is capable of hydroxylating and nitrating aromatic compounds, and inducing cellular injury by lipid peroxidation, DNA fragmentation, damage to proteins and plasma lipids, and depletion of important plasma antioxidants.(49)

As has been discussed, decreased availability of $\mathrm{BH}_{4}$ may increase oxidative stress, and a decrease in $\mathrm{BH}_{4}$ content in endothelial cells may indeed accelerate oxidative stress-induced endothelial cell death; (165)conversely, oxidative stress may contribute to decreased availability of functional pteridine cofactor by oxidative reactions. Under physiological conditions in vitro, peroxynitrite specifically oxidizes $\mathrm{BH}_{4}$.(166) Peroxynitrite-catalyzed oxidation of $\mathrm{BH}_{4}$ proceeds via two pathways from the quinoid $5,6-\mathrm{BH}_{2}$ intermediate. In one, a direct rearrangement to the more stable dihydro isomer 7,8- $\mathrm{BH}_{2}$ occurs, and this isomer may be reduced back to $\mathrm{BH}_{4}$. A large proportion of the quinoid $5,6-\mathrm{BH}_{2}$, however, loses its side-chain in the 6 position to form 7,8-dihydropterin, which can then be rapidly hydrated and converted to other species, including dihydroxanthoperin, thereby irreversibly losing cofactor function.(166) Finally, this may result in a vicious circle since limited bioavailability of $\mathrm{BH} 4$ uncouples L-arginine oxidation and increases eNOS-dependent superoxide production.

Autoxidation of $\mathrm{BH}_{4}$. In vitro, $\mathrm{BH}_{4}$ is susceptible to autoxidation in the presence of oxygen, (167-169) $\mathrm{BH}_{4}$ may react with oxygen to yield oxidized pteridines and ROI. $(102 ; 170 ; 171)$ Experiments with SOD suggest that superoxide is both a product of $\mathrm{BH}_{4}$ autoxidation and accelerator of the autoxidative process.(170) The distribution of oxidized pteridines is nearly identical to those formed after oxidation with peroxynitrite, again indicating that ROI are most likely involved in this process leading to irreversible loss of cofactor function of the pteridine.(166) Evidence for autoxidation of 
$\mathrm{BH}_{4}$ has also been obtained in isolated vessels in vitro, and exogenous $\mathrm{BH}_{4}$ regained the ability to stimulate endothelial NO synthesis anly after the addition of SOD. $(102 ; 109)$ Increased superoxide anions formed after $\mathrm{BH}_{4}$ autoxidation could also interact with $\mathrm{NO}$ resulting in peroxynitrite generation and additional subsequent oxidative destruction of $\mathrm{BH}_{4}$. These data imply that SOD may be critical for the effect of exogenous $\mathrm{BH}_{4}$ on the vasculature, at least under experimental conditions. It is, therefore, noticable that in vascular endothelial cells increased endogenous $\mathrm{BH}_{4}$ synthesis may be associated with simultanenous induction of SOD.(172) However, it is important to remember that all these findings have been obtained in vitro, and the relevance for in vivo conditions remains yet to be clarified.

Effects of exogenous $\mathrm{BH}_{4}$. Beneficial effects of $\mathrm{BH}_{4}$ on oxidative stress include specific actions, i.e. reduction of ROI generation by eNOS as well as rather unspecific mechanisms. Several studies confirm the potential of $\mathrm{BH}_{4}$, either in authentic form or given as sepiapterin, as antioxidant and scavenger of ROI, (173-178) see also reference (18) for review.

In line with the hypothesis of unspecific ROI scavenging is the observation that other pteridines, which share antioxidant and/or radical scavenging properties but no cofactor function with $\mathrm{BH}_{4}$, also protect various cells against oxidative stress, $(18 ; 179-186)$ and the $7,8-$ dihydrostucture of the pteridines was recognized to indicate strong scavenging potency.(187-189)

Antioxidants: interplay of $\mathrm{BH}_{4}$ with ascorbic acid (vitamin C) and folates?

Ascorbic acid. Lower dietary intake or plasma levels of ascorbic acid are associated with increased cardiovascular events. Conversely, ascorbic acid improves endothelium-dependent vasodilation in patients with coronary artery disease, risk factors for atherosclerosis, or chronic heart failure.(190) Prevention of oxidative modification of LDL, inhibition of leukocyte-endothelial cell interactions, and radical scavenging properties with prevented NO inactivation have been implicated,(191) however, ascorbic acid may not compete effectively with NO for superoxide at physiologically relevant concentrations, (192) and only results from studies using intraarterial ascorbic acid may be explained to a certain degree by superoxide scavenging. Another potential mechanism may depend on $\mathrm{BH}_{4}$. In vitro, intracellular $\mathrm{BH}_{4}$ levels are increased after treatment with ascorbic acid, $(96 ; 193 ; 194)$ and low concentrations of ascorbic acid enhance NO synthesis only when $\mathrm{BH}_{4}$ was omitted from cell lysate assays.(195) Likewise, pretreatment with ascorbic acid, which by itself dose-dependently augmented acetylcholine-mediated blood flow, abolished beneficial effects of $\mathrm{BH}_{4}$ on endothelium-dependent vasodilation in vivo.(112) The action of ascorbic acid does not seem to be mediated by increased $\mathrm{BH}_{4}$ biosynthesis, nor by modification of the pteridine affinity of eNOS, but may be due to chemical stabilization of $\mathrm{BH}_{4}$ (96) thereby optimizing endothelial NO synthesis.

Folates. Low serum folate levels are associated with an increased risk of cardiovascular events, $(196 ; 197)$ traditionally ascribed to the cofactor function for enzymes of homocysteine metabolism. Mechanisms contributing to vasculopathy include promotion of endothelial dysfunction, impaired regulation of EDRF and related nitrogen oxides, and decreased availability of NO.(198-200) $\mathrm{BII}_{4}$ may inhibit superoxide production induced by culturing of vascular cells with homocysteine.(201) Folate efficiently reduces plasma homocysteine levels and restores endothelial dysfunction induced by acute hyperhomocysteinemia.(202-205) In addition folate may improve endothelial function independently of its homocysteine-lowering effect that may include a reduction of ROI production by eNOS and other enzymes and increased availability of NO.(206;207) Interestingly, 5-methyltetrahydrofolate (5-MTHF) enhanced NO production and decreased superoxide production of partially pteridine-repleted but not of pteridine-free eNOS suggesting 5-MHTF to support $\mathrm{BH}_{4}$ as cofactor of eNOS.(208) The exact intracellular mechanism remains unknown at present.

\section{Endothelial dysfunction and atherosclerosis}

Endothelial dysfunction occurs early during the pathogenesis of atherosclerosis, adds to alterations in vascular function and structure, and may be pivotal for the progress of atherosclerosis. Causes of endothelial dysfunction include elevated and modified low-density lipoproteins (LDL), free radicals caused by cigarette smoking, hypertension, diabetes mellitus, genetic alterations, elevated plasma homocysteine concentrations, infectious microorganisms, and other yet unidentified factors. A number of these disorders are associated with reduced synthesis/availability or increased degradation of endothelium-derived $\mathrm{NO}$, and abnormal vasoreactivity is seen before morphological changes of atherosclerosis are visible. A growing body of evidence suggests increased production of ROI to be of pathophysiological importance contributing to inactivation of NO and endothelial dysfunction. $(84 ; 157 ; 203 ; 209-211)$

In patients with cardiovascular risk factors or clinically manifest atherosclerosis, exogenous L-arginine normalizes endothelium-dependent vasodilation and diminishes lesion formation. $(74 ; 84)$ The exact mecha- 
nism remain incompletely understood, but has mostly been attributed to an influence on eNOS activity. This is, at first glance, surprising since in vivo L-arginine concentrations appear to be well above the $\mathrm{Km}$ of eNOS for L-arginine,(212) and recently, it was suggested that effects independent of the role of L-arginine as substrate for eNOS may contribute as well.(212-216) A rapidly increasing number of studies demonstrates the potential of $\mathrm{BH}_{4}$ to reverse endothelial dysfunction associated with risk factors leading to atherosclerosis or even in patients with manifest atherosclerosis and suggests that $\mathrm{BH}_{4}$ may be of pivotal significance in the pathogenesis of this NO/oxidant imbalance.

Diabetes mellitus. Endothelial dysfunction is a common feature in experimental and clinical diabetes mellitus, and increased levels of ROI, release of an endothelium-derived constricting factor, and decreased endothelial NO synthesis are likely contributors to its pathogenesis.(210;217-219) Only little information is available concerning NOS activity, mRNA, and protein, but there is some evidence of normal or increased mRNA and protein levels despite impaired endothelial function due to a decrement of eNOS activity and increased endothelial superoxide generation. $(220 ; 221)$ Although in vitro $\mathrm{NO}$ synthesis was impaired, normal NOS activity was measured in cell homogenates under optimal conditions excluding an intrinsic defect in eNOS in these animals.(222)

Rat models of diabetes revealed an influence of the diabetic state on $\mathrm{BH}_{4}$ metabolism. In these animals de novo biosynthesis of $\mathrm{BH}_{4}$ as well as GTPCH and DHPR activities is reduced, and besides decreased $\mathrm{BH}_{4}$ levels, increased concentrations of more oxidized forms are measured; in contrast, the $\mathrm{BH}_{4}$ salvage pathway seems unaltered. Long-term oral treatment with $\mathrm{BH}_{4}$ increases GTPCH and eNOS activity without affecting eNOS protein or mRNA expression, improves endothelium-dependent relaxation, and normalizes superoxide production, membrane lipid peroxidation, and binding activity of redox-sensitive transcription factors; beneficial effects have also been reported with the lipid-soluble pteridine derivative 6methyl- $\mathrm{BH}_{4}$. In addition, insulin stimulates the synthesis of $\mathrm{BH}_{4}$ through activation of GTPCH in these animals, (221;223-226) and the endothelium-mediated vasorelaxation caused by insulin itself may be dependent on $\mathrm{BH}_{4}$. (227) The suggestion that $\mathrm{BH}_{4}$ biosynthesis might be reduced in diabetic conditions is supported by another study in LPS treated $\mathbf{J 7 7 4}$ macrophages.(228) Hitherto only limited information about human diabetes is available, but recent investigations indicate that $\mathrm{BH}_{4}$ improves vascular endothe- lial dysfunction also in patients with type 2 diabetes mellitus.(113)

Smoking. Smoking has adverse effects on the vascular endothelium, and endothelial dysfunction in chronic smokers that includes an impairment of basal and stimulated NO production is well established. This impairment may be reversible on smoking cessation. Endothelial dysfunction of smokers is multifactorial and not entirely understood, but increased stress due to ROI is likely to be of central importance.(229) Immunostaining experiments suggest impairment of eNOS activity but not protein expression by smoking. An inhibition of eNOS by aromatic amines from the combustion of tobacco has been proposed.(230) Other contributing factors may include free radicals from smoke that may react to form peroxynitrite, and the induction of superoxide production as a result of autoxidation of polyhdroxyaromatic compounds;(112) these data suggest oxidation of $\mathrm{BH}_{4}$ as the underlying cause of eNOS dysfunction, however, a formal proof for this hypothesis is lacking at the moment. $\mathrm{BH}_{4}$ or sepiapterin improve endothelial dysfunction in human saphenous veins from smokers in vitro, and concomittantly increased production of nitrite/nitrate and cGMP indicate restoration of L-arginine-NO-pathway activity.(230) $\mathrm{BH}_{4}$ also improves basal and endothelialdependent vasodilation of chronic smokers in vivo through a rather specific effect, most probably the reduction of NOS-derived ROI, and not by a nonspecific antioxidant action.(112)

Hypertension. Endothelium-derived NO production has repeatedly been found to be impaired in essential hypertension. Oxidative stress plays an important role in the pathogenesis of hypertension, and besides other sources a dysfunctional eNOS has been identified as producer of superoxide. $(203 ; 210 ; 231 ; 232)$ In spontaneously hypertensive rats, exogenous $\mathrm{BH}_{4}$ seemed not only to increase NO production but also to decrease levels of ROI although total biopterin levels in vessel walls were only slightly and non-significantly lower than in normotensive Wistar-Kyoto rats.(233) Only preliminary data are available on patients with essential hypertension. However, $\mathrm{BH}_{4}$ increased endothelium-dependent vasodilation in forearms of such patients in a way that was abolished by an NOS inhibitor.(234)

Hypercholesterolemia. Endothelial dysfunction in hypercholesterolemia with impaired NO generation has been associated with increased endothelial ROI production which is at least part caused by eNOS itself. $(210 ; 235)$ In patients with familial hypercholes- 
terolemia but without clinical signs of atherosclerosis, intraarterial administration of $\mathrm{BH}_{4}$ restored endothelium-dependent vasodilation; the action was only transient, and discontinuation of $\mathrm{BH}_{4}$ infusion resulted in reoccurrence of impaired NO activity within $20 \mathrm{~min}$ utes.(111) L-arginine is rate limiting in the L-arginineNO pathway in hypercholesterolemia, and L-arginine alone improves NO-dependent vasodilation in such patients.(235) However, L-arginine causes no further improvement in the presence of $\mathrm{BH}_{4}$ supplementation, indicating that functional $\mathrm{BH}_{4}$ deficiency may contribute to the "L-arginine paradox" by decreasing the affinity of eNOS for L-arginine.(111)

Clinically manifest atherosclerosis. In severely atherosclerotic mice lacking the apolipoprotein $\mathrm{E}$ and $\mathrm{LDL}$ receptor genes, $\mathrm{BH}_{4}$ slightly improved attenuated endothelium-dependent relaxation and, in combination with $\mathrm{L}$-arginine, induced a pronounced enhancement of endothelium-dependent vasorelaxation whereas Larginine alone was ineffective.(236) In nitrogylcerintolerant rats, $\mathrm{BH}_{4}$ alone improved endotheliumdependent vasodilation suggesting that altered bioavailability of $\mathrm{BH}_{4}$ may be of importance in this clinically relevant situation.(237) Interpretation of research on human atherosclerosis is hindered by the difficulty in obtaining true control vessels. However, there is evidence that basal NO release is impaired in atherosclerotic vessels, $(238 ; 239)$ and studies on human aortas indicate a downregulation of eNOS in endothelial cells overlying advanced atherosclerotic lesions.(240) These findings are supported by another study on arteries with advanced atherosclerosis obtained from patients undergoing carotid atherectomy or coronary bypass surgery in which eNOS protein and NO release was markedly diminished in luminal endothelial cells but not in endothelial cells of vasa vasorum inside the atherosclerotic plaque.(241) Consistent with these findings, differences in NO release observed in normal and atherosclerotic segments of explanted vein grafts are mirrored by focally reduced eNOS expression specific to atherosclerotic sites.(242) Despite the recurring observation of eNOS downregulation endothelial cells of atherosclerotic vessels, several studies demonstrated the potential of $\mathrm{BH}_{4}$ to improve endothelium-dependent vasodilation in patients with manifest atherosclerosis; e.g. in isolated human coronary arterioles from patients with significant coronary atherosclerosis,(239) and in vivo in patients with coronary artery disease.(243) Preliminary data also indicate the potential of $\mathrm{BH}_{4}$ to improve endothelium-dependent vasodilation and to reduce ROI generation in coronary arteries of patients with single or more cardiovascular risk factors but no sig- nificant coronary artery disease(244) and to enhance vasodilation in patients with atypical chest pain but angiographically normal coronary arteries.(245)

Recent immunohistochemical studies demonstrated the expression of iNOS in human and experimental atherosclerosis and a predominant presence in advanced atherosclerotic plaques, $(240 ; 246-249)$ however, no study hitherto performed has addressed the effects of $\mathrm{BH}_{4}$ on iNOS in atherosclerotic plaques.

Saphenous vein grafts. In saphenous vein segments from patients undergoing coronary artery bypass graft operations, $\mathrm{BH}_{4}$ roughly doubles actylcholine-induced vasorelaxation, indicating a dysfunctional endothelium already at the time of grafting.(250) Since in maturing vessel grafts endothelial NO synthesis may limit intimal hyperplasia, an improved supply of $\mathrm{BH}_{4}$ could improve the patency of vessel grafts, (230) but longterm studies will be required test this hypothesis.

Taken together, $\mathrm{BH}_{4}$ improves endothelial dysfunction associated with several risk factors for atherosclerosis or in manifest atherosclerosis. The biochemical background for a local functional $\mathrm{BH} 4$ deficiency in these disorders remains elusive, possible explanations include 1) increased oxidation of $\mathrm{BH} 4$ due to enhanced oxidative stress, and 2) decreased biosynthesis of the pteridine. The latter mechanism is supported by in vitro data demonstrating that oxidized LDL inhibits GTPCH gene expression in cytokine-activated cells.(251)

\section{Endothelial dysfunction and chronic heart failure}

Abnormalities in endothelial function with impaired endothelium-dependent vasorelaxation have also been described in patients with chronic heart failure, and ROI have been implicated in its pathogenesis. $(210 ; 252)$ To date, only preliminary and inconsistent data published in abstract form are available on the influence of $\mathrm{BH}_{4}$ on the vasculature in chronic heart failure. Whereas in one study an effect of $\mathrm{BH} 4$ on endothelium-dependent vasodilation was lacking, in another an improvement was found, $(253 ; 254)$ and clearly further work is needed to clarify the role of $\mathrm{BH}_{4}$ in this clinically important disease.

\section{$\mathrm{BH}_{4}$ and hypertension}

The importance of eNOS for control of systemic and eventually pulmonary hypertension has been confirmed by eNOS knockout mice.(86) In the healthy vasculature, however, $\mathrm{BH}_{4}$ requires rather high concentrations for hypotensive effects, as discussed earlier. Notwithstanding, $\mathrm{BH}_{4}$ restores endothelial dysfunction associated with hypertension, and under certain experimental conditions the pteridine also has some 
antihypertensive properties in animal models, e.g. in Male Sprague-Dawley rats fed high levels of fructose and uninephrectomized rats treated with deoxycorticosterone acetate and $1 \% \mathrm{NaCl}$ in the drinking water (DOCA-salt rats).(225;255)

Involvement of $\mathrm{BH}_{4}$ in ischemia-reperfusion (I/R) injury and "I/R tolerance"

Mechanisms of postischemic reperfusion (I/R) injury remain incompletely understood, but oxidative stress due to excess endothelial generation of ROI after the restoration of blood supply is thought to be of major importance.(158) In several animal models, exogenous sepiapterin, 6-methyl- $\mathrm{BH}_{4}$, or $\mathrm{BH}_{4}$ have shown beneficial effects on $\mathrm{I} / \mathrm{R}$ injury.(256-261) In contrast, no study has investigated so far whether exogenous $\mathrm{BH}_{4}$ also improves $\mathrm{I} / \mathrm{R}$ injury in man.

Although evidence for a beneficial effect of $\mathrm{BH}_{4}$ on $\mathrm{I} / \mathrm{R}$ injury is sound, only an indefinite idea about underlying processes exists and severai mechanisms likely contribute. $\mathrm{BH}_{4}$ has potential activity as antioxidant and scavenger of ROI in endothelial cells, and this unspecific property may be involved. Furthermore, since experiments using inhibitors of $\mathrm{BH}_{4}$ biosynthesis mimicked those from I/R experiments, $(257 ; 259)$ a decreased availability of functional pteridine cofactor is suspected in vessels exposed to $\mathrm{I} / \mathrm{R}$. As stated earlier, eNOS mediated ROI generation is triggered and controlled by decreased availability of $\mathrm{BH}_{4}$. Conversely, exogenous $\mathrm{BH}_{4}$ decreases superoxide levels by unspecific scavenging and reduction of eNOS dysfuntion.(51;52) Indeed, exogenous $\mathrm{BH}_{4}$ may restore impaired eNOS function and increase cGMP production after $\mathrm{I} / \mathrm{R}$ injury. $(256 ; 257 ; 259)$

The biochemical basis of eNOS impairment remains elusive. Giraldez et al. proposed a model to explain loss of eNOS activity occurring only after polonged I/R. They suggested intracellular acidosis to trigger titration of a critical amino acid (step 1) which would lead to further altered protein conformation with a partially unfolded protein (step 2). These two steps may be potentially reversible upon reperfusion. However, in a final step, the unfolded protein conformation would then be susceptible to proteolytic degradation, leading to the irreversible loss of enzyme activity.(262) Experiments with purified nNOS showed that stabilization of the dimeric state by $\mathrm{BH}_{4}$ reduces inactivation by ROI.(36) Although this remains to be formally confirmed for the eNOS isoform, recently increased total eNOS protein but decreased immunoreactivity for dimeric eNOS after experimental $\mathrm{I} / \mathrm{R}$ was demonstrated, and the latter was restored by additional $\mathrm{BH}_{4} .257$ Being not only confirmative for intracellular depletion of $\mathrm{BH}_{4}$ after $\mathrm{I} / \mathrm{R}$, these data also suggest depletion of $\mathrm{BH}_{4}$ to be of central importance for the stepwise loss of eNOS activity.

An unresolved issue remains how $I / R$ injury affects $\mathrm{BH}_{4}$ metabolism and results in diminished functionality of the pteridine. Although decreased de novo $\mathrm{BH}_{4}$ biosynthesis has been suggested,(257) the investigation was indirect; in fact, neither total biopterin contents nor expression of genes/enzyme activities involved in $\mathrm{BH}_{4}$ biosynthesis/regeneration have ever been measured during or after experimental I/R injury. However, it is conceivable to assume that enhanced oxidative stress within endothelial cells may result in oxidation of $\mathrm{BH}_{4}$ and loss of cofactor function, as outlined above.

Besides potentially disrupting and deleterious effects, $L / R$ can also induce a series of events within hours or days that renders tissues more resistant to subsequent $\mathrm{I} / \mathrm{R}$ insults. Recently, a critical dependence on activation and translocation of NF-kB for the development of "I/R tolerance" in endothelial cells was demonstrated.(90) Although both anoxia/reperfusion challenges were followed by transient increases in total eNOS protein, only the first was associated with increased oxidative stress, whereas after the second reduced oxidative stress was paralleled by increased NO production whith complete dependence on de novo $\mathrm{BH}_{4}$ biosynthesis. It was suggested that $\mathrm{NF}-\mathrm{kB}$ may contribute to the development of $I / R$ tolerance by transactivating the GTPCH gene, and increased $\mathrm{BH}_{4}$ levels would help to decrease subsequent I/R-induced cell damage.(90)

Vascular NOS gene therapy: requirement for $\mathrm{BH}_{4}$

Recently, NOSs have emerged as potential candidates for vascular gene therapy to restore deficient endothelial NO production in a variety of cardiovascular diseases. NOS vascular gene transfer restores or augments NOS activity in the vessel wall, modulates vascular smooth muscle cell biology, and leads to regression of early experimental atherosclerosis.(263) Only very limited information is available at present about the role of $\mathrm{BH}_{4}$ in NOS gene transfer. Almost all studies showed increased NO production after gene transfer without the addition of $\mathrm{BH}_{4}$. However, some data indicate that $\mathrm{BH}_{4}$ might be a limiting factor for the efficiency of NOS gene therapy. This is conceivable because 1) even under physiologic conditions $\mathrm{BH}_{4}$ has the potential to regulate vascular NO production, and 2) smooth muscle cells which are likely target cells do not constitutively synthesize $\mathrm{BH}_{4}$. In vitro, for example, additional sepiapterin significantly enhanced NO production in human vascular cells transfected with nNOS and porcine coronary artery smooth muscle cells transfected with eNOS. $(104 ; 264)$ In another 
study, human iNOS was transfered into vascular cells and isolated blood vessels. Whereas transfected smooth muscle cells strongly dependent on exogenous $\mathrm{BH}_{4}$ for $\mathrm{NO}$ synthesis, pulmonary endothelial cells obviously did not, and only porcine arteries transfected with human iNOS following balloon injury exhibited an increase in activity of NO-cGMP pathway over control vessels in a $\mathrm{BH}_{4}$ dependent fashion clearly indicating that the level of functional $\mathrm{BH}_{4}$ already present is a denominator whether exogenous $\mathrm{BH}_{4}$ has any additive effect.(265) Today, functional $\mathrm{BH}_{4}$ transfection by use of human GTPCH expression plasmids is technically feasible and reconstitutes near-maximal iNOS activity. Importantly, GTPCH and iNOS enzymes do not have to coexist within the same cells supporting the concept that $\mathrm{BH}_{4}$ produced in one cells is accessible to neighbouring NOS expressing cells.(107) Consequently, first in vitro and ex vivo experiments confirm the potential of co-transfected $\mathrm{BH}_{4}$ to enhance $\mathrm{NO}$ production achieved by gene transfe:.(266;267) Although further verification is awaited, it is clearly indicated that supplementation with $\mathrm{BH}_{4}$ may be required for efficient vascular NOS gene therapy, especially when the iNOS gene is transfected. It remains to be clarified whether cotransfection of GTPCH genc or direct administration of $\mathrm{BH}_{4}$ is preferable to deliver $\mathrm{BH}_{4}$ in these therapeutic settings.

Is $\mathrm{BH}_{4}$ critical for synthesis and biological effects of $V E G F-A$ ?

The vascular endothelial growth factor (VEGF) family consists of several members of angiogenetic growth factors among those VEGF-A has been best characterized.(268) The effect of NO on VEGF-A remains a matter of some debate. It has convincingly been demonstrated, however, that NO upregulates VEGF-A synthesis.(269) Conversely, actions of VEGF-A are partly mediated by endothelium-derived NO,(270-278) and long-term exposure of endothelial cells to VEGF-A increases eNOS $\mathrm{mRNA}$ and protein levels. $(279 ; 280)$ First evidence for a modulatory role of $\mathrm{BH}_{4}$ on cytokine-induced VEGF-A biosynthesis has recently been provided.(269) If confirmed, this finding may have some clinical significance as VEGF-A gene transfer is intensively studied as novel therapeutic approach to achieve angiogenesis in patients with symptomatic cardiovascular ischemic diseases.(281) In vivo data suggest a defective endothelial NO synthesis to be a limiting factor for the effect of VEGFA.(282) Since in atherosclerotic vessels a functional $\mathrm{BH}_{4}$ deficiency contributes to dysfunctional endothelial NO production, one may speculate that results of VEGF plasmid transfections could be critically dependent on local $\mathrm{BH}_{4}$ levels, and that restoration of
$\mathrm{BH}_{4}$ (pharmacologically or by co-transfection with $\mathrm{BH}_{4}$-encoding genes) could be a prerequisite for optimal treatment.

\section{$\mathrm{BH}_{4}$ and the pulmonary circulation}

Pulmonary endothelial cell changes occur early in most clinical and experimental forms of acute lung injury.(283) Abnormalities of endothelial function associated with an imbalance in the expression of endothelium-derived vasoactive substances, including reduced expression of eNOS and subsequent diminished NO production, have been demonstrated in a number of pulmonary diseases such as primary and secondary pulmonary hypertension, chronic obstructive lung disease, cardiopulmonary bypass, and congestive heart failure. (284-287)

Surprising to note the minimal knowledge about effects of $\mathrm{BH}_{4}$ in the lung. Although it is comprehensible to assume a regulation of pteridine synthesis similar to that in extrapulmonary tissues, experimental data to support this hypothesis are sparse. $(59 ; 149 ; 155$; 288) So far, pathophysiologic conditions associated with local $\mathrm{BH}_{4}$ deficiencies have not been described in the pulmonary circulation at all. Conversely, exogenous $\mathrm{BH}_{4}$ improved pulmonary endothelial dysfunction following $\mathrm{I} / \mathrm{R}$ injury by a mechanism involving the NO-cGMP pathway.(256) Further studies should clarify the role of $\mathrm{BH}_{4}$ in other lung disorders and the potential to improve them. In a preliminary study it was demonstrated that $\mathrm{BH}_{4}$ application by inhalation is feasible, well tolerated, and results in local resorption of $\mathrm{BH}_{4}$ in the lung with subsequent increases in plasma and urinary $\mathrm{BH}_{4}$ levels but without alteration of systemic hemodynamics.(114) Thus, inhalational $\mathrm{BH}_{4}$ may offer a basic tool for investigations on restoration of pulmonary endothelial dysfunction in future, and it remains to be seen whether local administration of $\mathrm{BH}_{4}$ by inhalation might be advantageous over systemic administration to achieve a therapeutic effect on endothelial dysfunction in the lung.

\section{Conclusions}

After more then a century of research on pteridine compounds it is now well established that $\mathrm{BH}_{4}$ is of central importance for vascular functions in health and disease. $\mathrm{BH}_{4}$ regulates vasomotion, modulates oxidative stress both by decreasing NOS-induced ROI generation and by unspecific ROI scavenging properties, is involved in effects of other pivotal antioxidants, and may be required in the signaling pathway of cellular mitogens and growth factors. A hitherto only uncompletely understood "BH 4 -deficiency" has been implicated in a number of acquired vascular disorders, and 
first clinical studies show promise with short-term $\mathrm{BH}_{4}-$ modifying treatment strategies. However, effects of long-term treatment with $\mathrm{BH}_{4}$ are largely unknown and are eagerly awaited to answer the question whether $\mathrm{BH}_{4}$, either supplemented as drug or via gene therapy, has the potential to prevent cardiovascular disease or to modify its clinical course.

\section{References}

1. Hopkins FG. Note on a yellow pigment in butterflies. Nature $1889 ; 40: 335$.

2. Kaufman S. New tetrahydrobiopterin-dependent systems. Annu Rev Nutr 1993; 13:261-286.

3. Kwon NS, Nathan CF, Stuehr DJ. Reduced biopterin as a cofactor in the generation of nitrogen oxides by murine macrophages. J Biol Chem 1989; 264:20496-20501.

4 Tayeh MA, Marletta MA. Macrophage oxidation of L-arginine to nitric oxide, nitrite, and nitrate. Tetrahydrobiopterin is required as a cofactor. J Biol Chem 1989; 264:19654-19658.

5 Mayer B, John M, Böhme E. Purification of a $\mathrm{Ca}^{2+} /$ calmodulin-dependent nitric oxide synthase from porcine cerebellum. Cofactor-role of tetrahydrobiopterin. FEBS Lett 1990; 277:215-219.

6 Pollock JS, Förstermann U, Mitchell JA, Warner TD, Schmidt HHHW, Nakane $\mathrm{M}$ et al. Purification and characterization of particulate endotheliumderived relaxing factor synthase from cultured and native bovine aortic endothelial cells. Proc Natl Acad Sci USA 1991; 88:10480-10484.

7 Nathan C, Shiloh MU. Reactive oxygen and nitrogen intermediates in the relationship between mammalian hosts and microbial pathogens. Proc Natl Acad Sci USA 2000; 97(16):8841-8848.

8 Schoedon G, Schneemann M, Walter R, Blau N, Hofer S, Schaffner A. Nitric oxide and infection: another view. Clin Infect Dis 1995; 21 (Suppl 2):S152-S157.

9 Furchgott RF, Zawadzki JV. The obligatory role of endothelial cells in the relaxation of arterial smooth muscle by acetylcholine. Nature $1980 ; 288: 373$ 376.

10 Palmer RM, Ferrige AG, Moncada S. Nitric oxide release accounts for the biological activity of endothelium-derived relaxing factor. Nature 1987; 327:524-526.

11 Ignarro LJ, Buga GM, Wood KS, Byrns RE, Chaudhuri G. Endothelium-derived relaxing factor produced and released from artery and vein is nitric oxide. Proc Natl Acad Sci LSA 1987; 84:92659269.

12 Blau N, Thöny B, Cotton RGH, Hyland K.
Disorders of tetahydrobiopterin and related biogenic amines. In: Scriver CR, Beaudet AL, Sly WS, Valle D, editors. The Metabolic and Molecular Basis of Inherited Disease. New York: McGrawHill, 2001: 1725-1776.

13 Thöny B, Auerbach G, Blau N. Tetrahydrobiopterin biosynthesis, regeneration and functions. Biochem J 2000; 347:1-16.

14 Koshimura K, Murakami Y, Tanaka J, Kato Y. The role of 6R-tetrahydrobiopterin in the nervous system. Prog Neurobiol 2000; 61:415-438.

15 Fitzpatrick PF. Tetrahydropterin-dependent amino acid hydroxylases. Annu Rev Biochem 1999; 68:355-381.

16 Nagatsu T, Ichinose H. Regulation of pteridinerequiring enzymes by the cofactor tetrahydrobiopterin. Mol Neurobiol 1999; 19:79-96.

17 Werner ER, Werner-Felmayer G, Mayer B. Tetrahydrobiopterin, cytokines, and nitric oxide synthesis. Proc Soc Exp Biol Med 1998; 219:171182.

18 Shimizu S, Ishii M, Momose K, Yamamoto Y. Role of tetrahydrobiopterin in the function of nitric oxide synthase, and its cytoprotective effect (review). Int J Mol Med 1998; 2:533-540.

19 Kinoshita H, Tsutsui M, Milstien S, Katusic ZS. Tetrahydrobiopterin, nitric oxide and regulation of cerebral arterial tone. Prog Neurobiol 1997; 52:295-302.

20 Auerbach G, Nar H. The pathway from GTP to tetrahydrobiopterin: Three-dimensional structures of GTP cyclohydrolase I and 6-pyruvoyl tetrahydropterin synthase. Biol Chem 1997; 378:185-192.

21 Werner ER, Werner-Felmayer $G$, Wachter $H$, Mayer B. Biosynthesis of nitric oxide: dependence on pteridine metabolism. Rev Physiol Biochem Pharmacol 1996; 127:97-135.

22 Duch DS, Smith GK. Biosynthesis and function of tetrahydrobiopterin. J Nutr Biochem 1991; 2:411423.

23 Nichol CA, Smith GK, Duch DS. Biosynthesis and metabolism of tetrahydrobiopterin and molybdopterin. Annu Rev Biochem 1985; 54:729-764.

24 Fitzpatrick PF. The aromatic amino acid hydroxylases. Adv Enzymol Relat Areas Mol Biol 2000; 74:235-294.

25 Hufton SE, Jennings IG, Cotton RGH. Structure and function of the aromatic amino acid hydroxylases. Biochem J 1995; 311:353-366.

26 Xia T, Gray DW, Shiman R. Regulation of rat liver phenylalanine hydroxylase. III. Control of catalysis by $(6 \mathrm{R})$-tetrahydrobiopterin and phenylalanine. J Biol Chem 1994; 269:24657-24665.

27 Mitnaul LJ, Shiman R. Coordinate regulation of 
tetrahydrobiopterin turnover and phenylalanine hydroxylase activity in rat liver cells. Proc Natl Acad Sci USA 1995; 92:885-889.

28 Stuehr DJ. Mammalian nitric oxide synthases. Biochim Biophys Acta 1999; 1411:217-230.

29 Andrew PJ, Mayer B. Enzymatic function of nitric oxide synthases. Cardiovasc Res 1999; 43:521531.

30 Poulos TL, Li H, Raman CS. Heme-mediated oxygen activation in biology: cytochrome c oxidase and nitric oxide synthase. Curr Opin Chem Biol 1999; 3:131-137.

31 Marletta MA, Hurshman AR, Rusche KM. Catalysis by nitric oxide synthase. Curr Opin Chem Biol 1998; 2:656-663.

32 Ortiz-de-Montellano PR, Nishida C, RodriguezCrespo I, Gerber N. Nitric oxide synthase structure and electron transfer. Drug Metab Dispos 1998; 26:1185-1189.

33 Michel T, Feron O. Nitric oxide synthases: which, where, how, and why? J Clin Invest 1997; 100:2146-2152.

34 Stuehr DJ. Structure-function aspects in the nitric oxide synthases. Annu Rev Pharmacol Toxicol 1997; 37:339-359.

35 Xia Y, Zweier JL. Direct measurement of nitric oxide generation from nitric oxide synthase. Proc Natl Acad Sci USA 1997; 94:12705-12710.

36 Kotsonis P, Fröhlich LG, Shutenko ZV, Horejsi R, Pfleiderer W, Schmidt HHHW. Allosteric regulation of neuronal nitric oxide synthase by tetrahydrobiopterin and suppression of auto-damaging superoxide. Biochem J 2000; 346:767-776.

37 Abu-Soud HM, Ichimori K, Presta A, Stuehr DJ. Electron transfer, oxygen binding, and nitric oxide feedback inhibition in endothelial nitric-oxide synthase. J Biol Chem 2000; 275:17349-17357.

38 Saura M, Pérez-Sala D, Canada FJ, Lamas S. Role of tetrahydrobiopterin availability in the regulation of nitric-oxide synthase expression in human mesangial cells. J Biol Chem 1996; 271:1429014295.

39 Linscheid P, Schaffner A, Schoedon G. Modulation of inducible nitric oxide synthase mRNA stability by tetrahydrobiopterin in vascular smooth muscle cells. Biochem Biophys Res Commun 1998; 243:137-141.

40 Pou S, Pou WS, Bredt DS, Snyder SH, Rosen GM. Generation of superoxide by purified brain nitric oxide synthase. J Biol Chem 1992; 267:2417324176.

41 Heinzel B, John M, Klatt P, Böhme E, Mayer B. $\mathrm{Ca}^{2+} /$ calmodulin-dependent formation of hydrogen peroxide by brain nitric oxide synthase. Biochem $\mathrm{J}$
$1992 ; 281: 627-630$.

42 Vásquez-Vivar J, Martásek P, Hogg N, Karoui H, Masters BSS, Pritchard KAJ et al. Electron spin resonance spin-trapping detection of superoxide generated by neuronal nitric oxide synthase. Methods Enzymol 1999; 301:169-177.

43 Xia Y, Dawson VL, Dawson TM, Snyder SH, Zweier JL. Nitric oxide synthase generates superoxide and nitric oxide in arginine-depleted cells leading to peroxynitrite-mediated cellular injury. Proc Natl Acad Sci USA 1996; 93:6770-6774.

44 Vásquez-Vivar J, Hogg N, Martásek P, Karoui H, Pritchard KAJ, Kalyanaraman B. Tetrahydrobiopterin-dependent inhibition of superoxide generation from neuronal nitric oxide synthase. J Biol Chem 1999; 274:26736-26742.

45 Abu-Soud HM, Gachhui R, Raushel FM, Stuehr DJ. The ferrous-dioxy complex of neuronal nitric oxide synthase. Divergent effects of L-arginine and tetrahydrobiopterin on its stability. J Biol Chem 1997; 272:17349-17353.

46 Gorren ACF, List BM, Schrammel A, Pitters E, Hemmens B, Werner ER et al. Tetrahydrobiopterin-free neuronal nitric oxide synthase: evidence for two identical highly anticooperative pteridine binding sites. Biochemistry 1996; 35:16735-16745.

47 Xia Y, Roman LJ, Masters BS, Zweier JL. Inducible nitric-oxide synthase generates superoxide from the reductase domain. J Biol Chem 1998; 273:22635-22639.

48 Xia Y, Zweier JL. Superoxide and peroxynitrite generation from inducible nitric oxide synthase in macrophages. Proc Natl Acad Sci USA 1997; 94:6954-6958.

49 Ronson RS, Nakamura M, Vinten-Johansen J. The cardiovascular effects and implications of peroxynitrite. Cardiovase Res 1999; 44:47-59.

50 Huisman A, Vanin A, Faassen EE, Rijn AJ, Martasek P, Rabelink TJ et al. Tetrahydrobiopterin shifts iNOS from a superoxide producing to a peroxynitrite producing enzyme. Circulation 2000; 102 (Suppl II):63.

51 Vásquez-Vivar J, Kalyanaraman B, Martásek P, Hogg N, Masters BS, Karoui H et al. Superoxide generation by endothelial nitric oxide synthase: the influence of cofactors. Proc Natl Acad Sci USA 1998; 95:9220-9225.

52 Xia Y, Tsai AL, Berka V, Zweier JL. Superoxide generation from endothelial nitric-oxide synthase. A $\mathrm{Ca}^{2+} /$ calmodulin-dependent and tetrahydrobiopterin regulatory process. J Biol Chem 1998; 273:25804-25808.

53 Vásquez-Vivar J, Martásek P, Kalyanaraman B. 
$\mathrm{BH}_{4} / \mathrm{BH}_{2}$ ratio but not ascorbate controls superoxide and nitric oxide generation by eNOS. Circulation 2000; 102 (Suppl II):63.

54 Liaudet L, Soriano FG, Szabo C. Biology of nitric oxide signaling. Crit Care Med 2000; 28 (Suppl):N37-N52.

55 Taguchi H, Armarego WL. Glyceryl-ether monooxygenase [EC 1.14.16.5]. A microsomal enzyme of ether lipid metabolism. Med Res Rev $1998 ; 18: 43-89$.

56 Dashman T, Samuels S, Leshinsky-Silver E, Kolodny E, Axelrod F. Tetrahydrobiopterin (BH4): Cofactor for dopamine beta hydroxylase (D beta H). FASEB J 1997; 11 (Suppl 2):A1311.

57 Wood JM, Schallreuter-Wood KU, Lindsey NJ, Callaghan S, Gardner ML. A specific tetrahydrobiopterin binding domain on tyrosinase controls melanogenesis. Biochem Biophys Res Commun $1995 ; 206: 480-485$.

58 Nishikimi M. A function of tetrahydropteridines as cofactors for indoleamine 2,3-dioxygenase. Biochem Biophys Res Commun 1975; 63:92-98.

59 Werner ER, Werner-Felmayer G, Fuchs D, Hausen A, Reibnegger G, Wachter H. Parallel induction of tetrahydrobiopterin biosynthesis and indoleamine 2,3-dioxygenase activity in human cells and cell lines by interferon-gamma. Biochem J 1989; 262:861-866.

60 Patterson EL, Broquist HP, Albrecht AM, von Saltza MH, Stokstad ELR. A new pteridine in urine required for the growth of the protozoon Crithidia fasciculata. J Am Chem Soc 1955; 77:3167-3168.

61 Curtius H-C, Blau N, Kuster T. Pterins. In: Hommes FA, editor. Techniques in Diagnostic Human Biochemical Genetics: A Laboratory Manual. New York: Wiley-Liss, 1991: 377-396.

62 Werner ER, Werner-Felmayer G, Wachter H. Highperformance liquid chromatographic methods for the quantification of tetrahydrobiopterin biosynthetic enzymes. J Chromatogr B Biomed Appl 1996; 684:51-58.

63 Koshimura K, Miwa S, Lee K, Fujiwara M, Watanabe Y. Enhancement of dopamine release in vivo from the rat striatum by dialytic perfusion of 6R-L-erythro-5,6,7,8-tetrahydrobiopterin. Neurochem 1990; 54:1391-1397.

64 Ziegler I. Production of pteridines during hematopoiesis and T-lymphocyte proliferation: potential participation in the control of cytokine signal transmission. Med Res Rev 1990; 10:95114.

65 Shimizu S, Yasuda M, Ishii M, Nagai T, Kiuchi Y, Yamamoto T. Stimulation of in vitro angiogenesis by tetrahydrobiopterin in bovine aortic endothelial cells. Jpn J Pharmacol 1999: \$

66 Anastasiadis PZ, Bezin L, Imermar 5.4. DM, Louie MC, Levine RA. Tetrahydrobiopte:-. as a mediator of $\mathrm{PC} 12$ cell proliferation induced $\mathrm{E}$ : EGF and NGF. Eur J Neurosci 1997; 9:1831-18:-

67 Anastasiadis PZ, Jiang H, Bezin L, Kuhn DM. Levine RA. Tetrahydrobiopterin enhances apoptotic PC12 cell death following withdrawal of trophic support. J Biol Chem 2001; 276:9050-9058.

68 Perez-Sala D, Diaz-Cazorla M, Ros J, Jimenez W, Lamas S. Tetrahydrobiopterin modulates cyclooxygenase-2 expression in human mesangial cells. Biochem Biophys Res Commun 1997; 241:7-12.

69 Schallreuter KU, Wood JM, Pittelkow MR, Gutlich $M$, Lemke KR, Rodl W et al. Regulation of melanin biosynthesis in the human epidermis by tetrahydrobiopterin. Science 1994; 263:1444-1446.

70 Moore J, Wood JM, Schallreuter KU. Evidence for specific complex formation between alphamelanocyte stimulating hormone and 6(R)-L-erythro-5, 6, 7,8-tetrahydrobiopterin using near infrared Fourier transform Raman spectroscopy. Biochemistry 1999; 38:15317-15324.

71 Schallreuter KU, Moore J, Tobin DJ, Gibbons NJ, Marshall HS, Jenner $\mathrm{T}$ et al. alpha-MSH can control the essential cofactor 6-tetrahydrobiopterin in melanogenesis. Ann N Y Acad Sci 1999; 885:329341 .

72 Schallreuter KU. A review of recent advances on the regulation of pigmentation in the human epidermis. Cell Mol Biol 1999; 45:943-949.

73 Schallreuter KU, Moore j, Wood JM, Beazley WD, Peters EM, Marles LK et al. Epidermal H(2)O(2) accumulation alters tetrahydrobiopterin (6BH4) recycling in vitiligo: identification of a general mechanism in regulation of all 6BH4-dependent processes? J Invest Dermatol 2001; 116:167-174.

74 Cines DB, Pollak ES, Buck CA, Loscalzo J, Zimmerman GA, McEver RP et al. Endothelial cells in physiology and in the pathophysiology of vascular disorders. Blood 1998; 91:3527-3561.

75 Vanhoutte PM, Mombouli JV. Vascular endothelium: vasoactive mediators. Prog Cardiovasc Dis 1996; 39:229-238.

76 Gruetter CA, Barry BK, McNamara DB, Gruetter DY, Kadowitz PJ, Ignarro LJ. Relaxation of bovine coronary artery and activation of coronary arterial guanylate cyclase by nitric oxide, nitroprusside and a carcinogenic nitrosoamine. J Cyclic Nucleotide Res 1979; 5:211-224.

77 Ignarro LJ, Byrns RE, Buga GM, Wood KS. Endothelium-derived relaxing factor from pulmonary artery and vein possesses pharmacologic and chemical properties identical to those of nitric 
oxide radical. Circ Res 1987; 61:866-879.

78 Ignarro LJ, Cirino G, Casini A, Napoli C. Nitric oxide as a signaling molecule in the vascular system: an overview. J Cardiovasc Pharmacol 1999; 34:879-886.

79 Bredt DS, Snyder SH. Nitric oxide: a physiologic messenger molecule. Annu Rev Biochem 1994; 63:175-195.

80 Nathan C, Xie QW. Nitric oxide synthases: roles, tolls, and controls. Cell 1994; 78:915-918.

81 Schmidt HHHW, Walter U. NO at work. Cell 1994; 78:919-925.

82 Lowenstein CJ, Dinerman JL, Snyder SH. Nitric oxide: a physiologic messenger. Ann Intern Med 1994; 120:227-237.

83 Moncada S, Palmer RM, Higgs EA. Nitric oxide: physiology, pathophysiology, and pharmacology. Pharmacol Rev 1991; 43:109-142.

84 Cooke JP, Dzau VJ. Nitric oxide synthase: role in the genesis of vascular disease. Annu Rev Med 1997; 48:489-509.

85 Loscalzo J, Welch G. Nitric oxide and its role in the cardiovascular system. Prog Cardiovase Dis 1995; 38:87-104.

86 Papapetropoulos A, Rudic RD, Sessa WC. Molecular control of nitric oxide synthases in the cardiovascular system. Cardiovasc Res 1999; 43:509-520.

87 MacNaul KL, Hutchinson NI. Differential expression of INOS and CNOS mRNA in human vascular smooth muscle cells and endothelial cells under normal and inflammatory conditions. Biochem Biophys Res Commun 1993; 196:1330-1334.

88 Rosenkranz-Weiss P, Sessa WC, Milstien S, Kaufman S, Watson CA, Pober JS. Regulation of nitric oxide synthesis by proinflammatory cytokines in human umbilical vein endothelial cells. Elevations in tetrahydrobiopterin levels enhance endothelial nitric oxide synthase specific activity. J Clin Invest 1994; 93:2236-2243.

89 Linscheid P, Schaffner A, Blau N, Schoedon G. Regulation of 6-pyruvoyltetrahydropterin synthase activity and messenger RNA abundance in human vascular endothelial cells. Circulation 1998; 98:1703-1706

90 Cepinskas G, Lush CW, Kvietys PR. Anoxia/reoxygenation-induced tolerance with respect to polymorphonuclear leukocyte adhesion to cultured endothelial cells. A nuclear factorkappaB-mediated phenomenon. Circ Res 1999; 84:103-112.

9 Hobbs AJ, Ignarro LJ. The nitric oxide - cyclic GMP signal transduction system. In: Zapol WM, Bloch KD, editors. Nitric Oxide and the Lung. New
York: Mareel Dekker Inc., 1997: 1-57.

92 Werner-Felmayer G. Werner ER, Fuchs D, Hausen A, Reibnegger G. Schmidt $\mathrm{K}$ et al. Pteridine biosynthesis in human endothelial cells. Impact on nitric oxide-mediated formation of cyclic GMP. J Biol Chem 1993: 268:1842-1846.

93 Schoedon G, Schneemann M, Blau N, Edgell C-JS, Schaffner A. Modulation of human endothelial cell tetrahydrobiopterin synthesis by activating and deactivating cytokines: new perspectives on endothelium-derived relaxing factor. Biochem Biophys Res Commun 1993; 196:1343-1348.

94 Katusic ZS, Stelter A, Milstien S. Cytokines stimulate GTP cyclohydrolase 1 gene expression in cultured human umbilical vein endothelial cells. Arterioscler Thromb Vasc Biol 1998; 18:27-32.

95 Schmidt K, Werner ER, Mayer B, Wachter H, Kukovetz WR. Tetrahydrobiopterin-dependent formation of endothelium-derived relaxing factor (nitric oxide) in aortic endothelial cells. Biochem $\mathrm{J}$ 1992; 281:297-300.

96 Heller R, Unbehaun A, Schellenberg B, Mayer B, Werner-Felmayer G, Werner ER. L-ascorbic acid potentiates endothelial nitric oxide synthesis via a chemical stabilization of tetrahydrobiopterin. J Biol Chem 2001; 276:40-47.

97 Schaffner A, Blau N, Schneemann M, Steurer J, Edgell C-JS, Schoedon G. Tetrahydrobiopterin as another EDRF in man. Biochem Biophys Res Commun 1994; 205:516-523.

98 Duch DS, Bowers SW, Woolf JH, Nichol CA. Biopterin cofactor biosynthesis: GTP cyclohydrolase, neopterin and biopterin in tissues and body fluids of mammalian species. Life Sci 1984; 35:1895-1901.

99 Schoedon G, Niederwieser A, Curtius H-C, Fontana A, Troppmair J, Huber C. Metabolism of pterins in the cellular immune system of man and mouse. In: Curtius H-C, Blau N, Levine RA, editors. Unconjugated Pterins and Related Biogenic Amines. Berlin, New York: Walter de Gruyter, 1987: 161-168.

100 Hwang O, Choi HJ, Park SY. Up-regulation of GTP cyclohydrolase I and tetrahydrobiopterin by calcium influx. Neuroreport 1999; 10:3611-3614.

101 Van Amsterdam JGC, Wemer J. Tetrahydrobiopterin induces vasodilation via enhancement of cGMP level. Eur J Pharmacol 1992; 215:349-350.

102 Tsutsui M, Milstien S, Katusic ZS. Effect of tetrahydrobiopterin on endothelial function in canine middle cerebral arteries. Circ Res 1996; 79:336-342.

103 Walter R, Linscheid P, Blau N, Kierat L, Schaffner 
A, Schoedon G. Induction of tetrahydrobiopterin synthesis in human umbilical vein smooth muscle cells by inflammatory stimuli. Immunol Lett 1998; 60:13-17.

104 Channon KM. Blazing MA, Shetty GA, Potts KE, George SE. Adenoviral gene transfer of nitric oxide synthase: high level expression in human vascular cells. Cardiovasc Res 1996; 32:962-972.

105 Gross SS, Levi R. Tetrahydrobiopterin synthesis. An absolute requirement for cytokine-induced nitric oxide generation by vascular smooth muscle. J Biol Chem 1992; 267:25722-25729.

106 Walter R, Blau N, Kierat L, Schaffner A, Schoedon G. Effects of activating and deactivating cytokines on the functionally linked tetrahydrobiopterin NO pathways in vascular smooth muscle cells. Immunol Lett 1996; 54:25-29.

107 Tzeng E, Yoneyama T, Hatakeyama K, Shears LLI, Billiar TR. Vascular inducible nitric oxide synthase gene therapy: requirement for guanosine triphosphate cyclohydrolase I. Surgery 1996; 120:315321.

108 Van Amsterdam JGC, Eigeman L, van de Kuil A, Wemer J. Relaxation of vascular smooth muscle and stimulation of cyclic GMP production by tetrahydrobiopterin but not biopterin. In: Pfleiderer W, Rokos H, editors. Chemistry and Biology of Pteridines and Folates 1997. Berlin, Vienna: Blackwell Wiss.-Verl., 1997: 675-678.

109 Kinoshita H, Katusic ZS. Exogenous tetrahydrobiopterin causes endothelium-dependent contractions in isolated canine basilar artery. Am J Physiol 1996; $271: \mathrm{H} 738-\mathrm{H} 743$.

110 Rosenblum WI. Tetrahydrobiopterin, a cofactor for nitric oxide synthase, produces endotheliumdependent dilation of mouse pial arterioles. Stroke 1997; 28:186-189

111 Stroes E, Kastelein J, Cosentino F, Erkelens W, Wever R, Koomans $\mathrm{H}$ et al. Tetrahydrobiopterin restores endothelial function in hypercholesterolemia. J Clin Invest 1997; 99:41-46.

112 Heitzer T, Brockhoff C, Mayer B, Warnholtz A, Mollnau H, Henne $\mathrm{S}$ et al. Tetrahydrobiopterin improves endothelium-dependent vasodilation in chronic smokers : evidence for a dysfunctional nitric oxide synthase. Circ Res 2000: 86:E36-E41.

113 Heitzer $T$, Krohn $K$, Albers $S$. Meinertz $T$. Tetrahydrobiopterin improves endotheliumdependent vasodilation by increasing nitric oxide activity in patients with type II diabetes mellitus. Diabetologia 2000; 43:1435-1438

114 Walter R, Blau N, Schaffner A. Schneemann 11. Speich R, Stocker R et al. Inhalation of the nitric oxide synthase cofactor tetrahydrobiontern in healthy volunteers. Am J Respir Crit Care Med 1997; 156:2006-2010.

115 Bhagat K, Hingorani AD, Palacios M, Charles IG, Vallance P. Cytokine-induced venodilatation in humans in vivo: eNOS masquerading as iNOS. Cardiovasc Res 1999; 41:754-764.

116 Walter R, Kaufmann PA, Buck A, Berthold T, Wyss $C$, von Schulthess GK et al. Tetrahydrobiopterin increases myocardial blood flow in healthy volunteers: a double-blind, placebo controlled study. Swiss Med Wkly 2001; 131:91-94.

117 Fleming I, Busse R. Signal transduction of eNOS activation. Cardiovasc Res 1999; 43:532-541.

118 Förstermann $\mathrm{U}$, Boissel JP, Kleinert $\mathrm{H}$ Expressional control of the 'constitutive' isoforms of nitric oxide synthase (NOS I and NOS III) FASEB J 1998; 12:773-790.

119 Fleming I, Dambacher T, Busse R. Endotheliumderived kinins account for the immediate response of endothelial cells to bacterial lipopolysaccharide. J Cardiovasc Pharmacol 1992; 20 (Suppl 12):S135S138.

120 Nishida K, Harrison DG, Navas JP, Fisher AA, Dockery SP, Uematsu $M$ et al. Molecular cloning and characterization of the constitutive bovine aortic endothelial cell nitric oxide synthase. J Clin Invest 1992; 90:2092-2096.

121 Marsden PA, Schappert KT, Chen HS, Flowers M, Sundell CL, Wilcox JN et al. Molecular cloning and characterization of human endothelial nitric oxide synthase. FEBS Lett 1992; 307:287-293.

122 Myers PR, Wright TF, Tanner MA, Adams HR. EDRF and nitric oxide production in cultured endothelial cells: direct inhibition by $\mathrm{E}$. coli endotoxin. Am J Physiol 1992; 262:H710-H718.

123 Walter R, Schaffner A, Schoedon G. Differential regulation of constitutive and inducible nitric oxide production by inflammatory stimuli in murine endothelial cells. Biochem Biophys Res Commun 1994; 202:450-455.

124 Yoshizumi M, Perrella MA, Burnett JCJ, Lee M-E. Tumor necrosis factor downregulates an endothelial nitric oxide synthase mRNA by shortening its half-life. Circ Res 1993; 73:205-209.

125 Mohamed F, Monge JC, Gordon A, Cernacek P, Blais D, Stewart DJ. Lack of role for nitric oxide (NO) in the selective destabilization of endothelial NO synthase mRNA by tumor necrosis factoralpha. Arterioscler Thromb Vasc Biol 1995; 15:5257.

$126 \mathrm{Lu}$ J-L, Schmiege LMI, Kuo L, Liao JC. Downregulation of endothelial constitutive nitric oxide synthase expression by lipopolysaccharide. Biochem Biophys Res Commun 1996; 225:1-5. 
127 Inoue N, Venema RC, Sayegh HS, Ohara Y, Murphy TJ, Harrison DG. Molecular regulation of the bovine endothelial cell nitric oxide synthase by transforming growth factor-beta 1. Arterioscler Thromb Vasc Biol 1995; 15:1255-1261.

128 Annane D, Sanquer S, Sebille V, Faye A, Djuranovic D, Raphael JC et al. Compartmentalised inducible nitric-oxide synthase activity in septic shock. Lancet 2000 ; 355:11431148.

129 Bhagat K, Vallance P. Effects of cytokines on nitric oxide pathways in human vasculature. Curr Opin Nephrol Hypertens 1999; 8:89-96.

130 Gross SS, Jaffe EA, Levi R, Kilbourn RG. Cytokine-activated endothelial cells express an isotype of nitric oxide synthase which is tetrahydrobiopterin-dependent, calmodulin-independent and inhibited by arginine analogs with a rank-order of potency characteristic of activated macrophages. Biochem Biophys Res Commun 1991; 178:823829.

131 Radomski MW, Palmer RMJ, Moncada S. Glucocorticoids inhibit the expression of an inducible, but not the constitutive, nitric oxide synthase in vascular endothelial cells. Proc Natl Acad Sci USA $1990 ; 87: 10043-10047$.

132 Marumo T, Nakaki T, Adachi H, Esumi H, Suzuki $\mathrm{H}$, Saruta $\mathrm{T}$ et al. Nitric oxide synthase mRNA in endothelial cells: synergistic induction by interferon-gamma, tumor necrosis factor-alpha and lipopolysaccharide and inhibition by dexamethasone. Jpn J Pharmacol 1993; 63:327-334.

133 Kanno K, Hirata Y, Imai T, Iwashina M, Marumo F. Regulation of inducible nitric oxide synthase gene by interleukin- 1 beta in rat vascular endothelial cells. Am J Physiol 1994; 267:H2318-H2324.

134 Lamas S, Michel T, Collins T, Brenner BM, Marsden PA. Effects of interferon-gamma on nitric oxide synthase activity and endothelin-1 production by vascular endothelial cells. J Clin Invest 1992; 90:879-887.

135 Hattori Y, Gross SS. GTP cyclohydrolase I mRNA is induced by LPS in vascular smooth muscle: characterization, sequence and relationship to nitric oxide synthase. Biochem Biophys Res Commun $1993 ; 195: 435-441$

136 Hattori Y, Nakanishi N, Kasai K, Shimoda S-I. GTP cyclohydrolase I mRNA induction and tetrahydrobiopterin synthesis in human endothelial cells. Biochim Biophys Acta 1997; 1358:61-66.

137 Mühl H, Pfeilschifter J. Tetrahydrobiopterin is a limiting factor of nitric oxide generation in interleukin 1 beta-stimulated rat glomerular mesangial cells. Kidney Int 1994; 46:1302-1306.
138 Schoedon G. Blau N, Schneemann M, Flury G, Schaffner A. Nitric oxide production depends on preceding tetrahydrobiopterin synthesis by endothelial cells: selective suppression of induced nitric oxide production by sepiapterin reductase inhibitors. Biochem Biophys Res Commun 1994; 199:504-510.

139 Werner-Felmayer G, Werner ER, Fuchs D, Hausen A, Reibnegger G, Wachter H. Tetrahydrobiopterindependent formation of nitrite and nitrate in murine fibroblasts. J Exp Med 1990; 172:1599-1607.

140 Jorens PG, Van Overveld FJ, Vermeire PA, Bult H, Herman AG. Synergism between interleukin-1 beta and interferon-gamma, an inducer of nitric oxide synthase, in rat lung fibroblasts. Eur $\mathrm{J}$ Pharmacol 1992; 224:7-12.

141 Sakai N, Kaufman S, Milstien S. Tetrahydrobiopterin is required for cytokineinduced nitric oxide production in a murine macrophage cell line (RAW 264). Mol Pharmacol 1993; 43:6-10.

142 Kasai K, Hattori Y, Nakanishi N, Manaka K, Banba $\mathrm{N}$, Motohashi $\mathrm{S}$ et al. Regulation of inducible nitric oxide production by cytokines in human thyrocytes in culture. Endocrinology 1995; 136:4261-4270.

143 Nussler AK, Liu ZZ, Hatakeyama K, Geller DA, Billiar TR, Morris SMJ. A cohort of supporting metabolic enzymes is coinduced with nitric oxide synthase in human tumor cell lines. Cancer Lett 1996; 103:79-84.

145 Hattori Y, Hattori S, Motohashi S, Kasai K, Shimoda SI, Nakanishi N. Co-induction of nitric oxide and tetrahydrobiopterin synthesis in the myocardium in vivo. Mol Cell Biochem 1997; 166:177-181.

145 Schoedon G, Schneemann M, Hofer S, Guerrero L, Blau N, Schaffner A. Regulation of the L-argininedependent and tetrahydrobiopterin-dependent biosynthesis of nitric oxide in murine macrophages. Eur J Biochem 1993; 213:833-839.

146 Bune AJ, Cook HT. Inhibition of tetrahydrobiopterin synthesis reduces nitric oxide production by isolated glomeruli in immune complex glomerulonephritis. Exp Nephrol 1996; 4:43-47.

147 Werner-Felmayer G, Prast H, Werner ER, Philippu A, Wachter H. Induction of GTP cyclohydrolase I by bacterial lipopolysaccharide in the rat. FEBS Lett 1993; 322:223-226.

148 Hattori Y, Oka M, Kasai K, Nakanishi N, Shimoda $\mathrm{S}-\mathrm{I}$. Lipopolysaccharide treatment in vivo induces tissue expression of GTP cyclohydrolase I mRNA. FEBS Lett 1995; 368:336-338.

149 Hattori Y, Nakanishi N, Kasai K, Murakami Y, Shimoda S. Tetrahydrobiopterin and GTP cyclohy- 
drolase I in a rat model of endotoxic shock: relation to nitric oxide synthesis. Exp Physiol 1996; 81:665-671.

150 Strohmaier W, Werner ER, Wachter H, Redl H, Schlag G. Pteridine and nitrite/nitrate formation in experimental septic and traumatic shock. Shock $1996 ; 6: 254-258$.

151 Van Amsterdam JGC, van den Berg C, Zuidema J, te-Biesebeek JD, Rokos H. Effect of septicaemia on the plasma levels of biopterin and nitric oxide metabolites in rats and rabbits. Biochem Pharmacol 1996; 52:1447-1451.

152 Greenberg SS, Xie J, Joseph KO, Kolls J, Summer $W$. In vivo administration of endotoxin and tumor necrosis factor-alpha produce different effects on constitutive and inducible nitric oxide synthase activity in rat neutrophils and aorta ex vivo. Proc Soc Exp Biol Med 1995; 208:199-208.

153 Klemm P, Ostrowski J, Morath T, Gruber C, Martorana PA, Henning R. N-Acetylserotonin prevents the hypotension induced by bacterial lipopolysaccharides in the rat. Eur J Pharmacol 1993; 250:R9-R10.

154 Bune AJ, Brand MP, heales SJ, Shergill JK, Cammack R, Cook HT. Inhibition of tetrahydrobiopterin synthesis reduces in vivo nitric oxide production in experimental endotoxic shock. Biochem Biophys Res Commun 1996; 220:13-19.

155 Hattori Y, Akimoto K, Nakanishi N, Kasai K. Glucocorticoid regulation of nitric oxide and tetrahydrobiopterin in a rat model of endotoxic shock. Biochem Biophys Res Commun 1997; 240:298-303.

156 Hoshiai K, Hattan N, Fukuyama N, Tadaki F, Hida $M$, Saito $A$ et al. Increased plasma tetrahydrobiopterin in septic shock is a possible therapeutic target. Pathophysiology 2001; 7:275-281.

157 Cai H, Harrison DG. Endothelial dysfunction in cardiovascular diseases: the role of oxidant stress. Circ Res 2000; 87:840-844.

158 Pohlman TH, Harlan JM. Adaptive responses of the endothelium to stress. J Surg Res 2000; 89:85119.

159 Wolin MS. Interactions of oxidants with vascular signaling systems. Arterioscler Thromb Vasc Biol $2000 ; 20: 1430-1442$.

160 Cosentino F, Katusic ZS. Tetrahydrobiopterin and dysfunction of endothelial nitric oxide synthase in coronary arteries. Circulation 1995; 91:139-144.

161 Kinoshita H, Milstien S, Wambi C, Katusic ZS. Inhibition of tetrahydrobiopterin biosynthesis impairs endothelium-dependent relaxations in canine basilar artery. Am J Physiol 1997; 273:H718-H724.
162 Hishikawa K, Lüscher TF. Pulsatile stretch stimulates superoxide production in human aortic endothelial cells. Circulation 1997; 96:3610-3616.

163 Laursen JB, Somers M, Kurz S, McCann L, Warnholtz A, Freeman BA et al. Endothelial regulation of vasomotion in apoE-deficient mice: implications for interactions between peroxynitrite and tetrahydrobiopterin. Circulation 2001; 103:12821288.

164 Beckman JS, Beckman TW, Chen J, Marshall PA, Freeman BA. Apparent hydroxyl radical production by peroxynitrite: implications for endothelial injury from nitric oxide and superoxide. Proc Natl Acad Sci USA 1990; 87:1620-1624.

165 Ishii M, Shimizu S, Yamamoto T, Momose K, Kuroiwa Y. Acceleration of oxidative stressinduced endothelial cell death by nitric oxide synthase dysfunction accompanied with decrease in tetrahydrobiopterin content. Life Sci 1997; 61:739. 747.

166 Milstien S, Katusic Z. Oxidation of tetrahydrobiopterin by peroxynitrite: implications for vascular endothelial function. Biochem Biophys Res Commun 1999; 263:681-684.

167 Fisher DB, Kaufman S. Tetrahydropterin oxidation without hydroxylation catalyzed by rat liver phenylalanine hydroxylase. J Biol Chem 1973: 248:4300-4304.

168 Armarego WL, Randles D, Taguchi H. Peroxidase catalysed aerobic degradation of 5,6,7,8-tetrahydrobiopterin at physiological $\mathrm{pH}$. Eur $\mathrm{J}$ Biochem 1983; 135:393-403.

169 Davis MD, Kaufman S, Milstien S. The auto-oxidation of tetrahydrobiopterin. Eur J Biochem 1988; 173:345-351

170 Davis MD, Kaufman S. Products of the tyrosinedependent oxidation of tetrahydrobiopterin by rat liver phenylalanine hydroxylase. Arch Biochem Biophys 1993; 304:9-16.

171 Mayer B, Klatt P, Werner ER, Schmidt K. Kinetics and mechanism of tetrahydrobiopterin-induced oxidation of nitric oxide. J Biol Chem 1995; 270:655-659.

172 Wong GH, Goeddel DV. Induction of manganous superoxide dismutase by tumor necrosis factor: possible protective mechanism. Science 1988; 242:941-944.

173 Shen R, Zhang Y. Reduced pterins as scavengers for reactive oxygen species. Adv Exp Med Biol 1993; 338:351-354.

174 Kojima S, Ona S, Iizuka I, Arai T, Mori H, Kubota K. Antioxidative activity of 5,6,7,8-tetrahydrobiopterin and its inhibitory effect on paraquatinduced cell toxicity in cultured rat hepatocytes. 
Free Radic Res 1995; 23:419-430.

175 Ishii M, Shimizu S, Momose K, Yamamoto T. Reduction by tetrahydrobiopterin of $\mathrm{H} 2 \mathrm{O} 2$ induced endothelial cell injury. Pharmacol Toxicol 1998; 82:280-286.

176 Kojima S, Nimura K, Komatsu H, Taguchi T, Iizuka $\mathrm{H}$. Modulation of S-nitroso-N-acetyl-D,Lpenicillamine (SNAP) induced HL-60 cell death by tetrahydrobiopterin. Anticancer Res 1997; 17:929. 937.

177 Ishii M, Shimizu S, Momose K, Yamamoto T. SIN1 -induced cytotoxicity in cultured endothelial cells involves reactive oxygen species and nitric oxide: protective effect of sepiapterin. J Cardiovasc Pharmacol 1999; 33:295-300.

178 Shimizu S, Ishii M, Kawakami Y, Momose K, Yamamoto T. Protective effects of tetrahydrobiopterin against nitric oxide-induced endothelial cell death. Life Sci 1998; 63:1585-1592.

179 Reibnegger G, Horejsi R, Oettl K. Pteridines as modulators of free radical-induced reactions: an overview. In: Pfleiderer W, Rokos H, editors. Chemistry and Biology of Pteridines and Folates 1997. Berlin, Vienna: Blackwell Wiss.-Verl., 1997: 783-790.

180 Kojima S, Icho T, Kajiwara Y, Kubota K. Neopterin as an endogenous antioxidant. FEBS Lett 1992; 304:163-166.

181 Kojima S, Nomura T, Icho T, Kajiwara Y, Kitabatake K, Kubota K. Inhibitory effect of neopterin on NADPH-dependent superoxide-generating oxidase of rat peritoneal macrophages. FEBS Lett 1993; 329:125-128.

182 Icho T, Kojima S, Shinohara N, Kajiwara Y, Kitabatake K, Kubota K. Protective effects of tetrahydroneopterin against free radical-induced injury. Biochem Pharmacol 1993; 45:1953-1958.

183 Kojima S, Icho T, Hayashi M, Kajiwara Y, Kitabatake K, Kubota K. Inhibitory effect of 5,6,7,8-tetrahydroneopterin on adriamycin-induced cardiotoxicity. J Pharmacol Exp Ther 1993; 266:1699-1704.

184 Icho T, Kojima S, Hayashi M, Kajiwara Y, Kitabatake K, Kubota K. Suppression of ischemiareperfusion injury in murine models by neopterins. Toxicol Appl Pharmacol 1995; 130:27-31.

185 Weiss G, Fuchs D, Hausen A, Reibnegger G, Werner ER, Werner-Felmayer $G$ et al. Neopterin modulates toxicity mediated by reactive oxygen and chloride species. FEBS Lett 1993; 321:89-92.

186 Kurobane T, Kojima S, Yoshimura M, Icho T, Kajiwara Y, Kubota K. Effect of 5,6,7,8-tetrahydroneopterin on the bovine endothelial cell injury induced by cumene hydroperoxide. Jpn J
Pharmacol 1995; 68:263-269.

187 Reibnegger G, Fuchs D, Murr C, Dierich MP, Pfleiderer W, Wachter H. Effects of pteridines on luminol-dependent chemiluminescence induced by chloramine-T. Free Radic Biol Med 1995; 18:515523.

188 Gieseg SP, Reibnegger G, Wachter H, Esterbauer H. 7,8 Dihydroneopterin inhibits low density lipoprotein oxidation in vitro. Evidence that this macrophage secreted pteridine is an anti-oxidant. Free Radic Res 1995; 23:123-136.

189 Oettl K, Dikalov S, Freisleben HJ, Mlekusch W, Reibnegger G. Spin trapping study of antioxidant properties of neopterin and 7,8-dihydroneopterin. Biochem Biophys Res Commun 1997; 234:774778.

190 Carr AC, Frei B. Toward a new recommended dietary allowance for vitamin $\mathrm{C}$ based on antioxidant and health effects in humans. Am $\mathbf{J}$ Clin Nutr 1999; 69:1086-1107.

191 Carr AC, Zhu B-Z, Frei B. Potential antiatherogenic mechanisms of ascorbate (vitamin C) and alpha-tocopherol (vitamin E). Circ Res 2000; 87:349-354

192 Jackson TS, Xu A, Vita JA, Keaney JFJ. Ascorbate prevents the interaction of superoxide and nitric oxide only at very high physiological concentrations. Circ Res 1998; 83:916-922.

193 Huang A, Vita JA, Venema RC, Keaney JFJ. Ascorbic acid enhances endothelial nitric-oxide synthase activity by increasing intracellular tetrahydrobiopterin. J Biol Chem 2000; 275 :1739917406.

194 Baker TA, Milstien S, Katusic ZS. Effect of vitamin $C$ on the availability of tetrahydrobiopterin in human endothelial cells. J Cardiovasc Pharmacol $2001 ; 37: 333-338$

195 Heller R, Münscher-Paulig F, Gräbner R, Till U. LAscorbic acid potentiates nitric oxide synthesis in endothelial cells. J Biol Chem 1999; 274:82548260 .

196 Giles WH, Kittner SJ, Anda RF, Croft JB, Casper ML. Serum folate and risk for ischemic stroke. First National Health and Nutrition Examination Survey epidemiologic follow-up study. Stroke 1995; 26:1166-1170.

197 Morrison HI, Schaubel D, Desmeules M, Wigle DT. Serum folate and risk of fatal coronary heart disease. JAMA 1996; 275:1893-1896.

198 Woo KS, Chook P, Lolin YI, Cheung AS, Chan LT, Sun YY et al. Hyperhomocyst(e)inemia is a risk factor for arterial endothelial dysfunction in humans. Circulation 1997; 96:2542-2544.

199 Stamler JS, Osborne JA, Jaraki O, Rabbani LE, 
Mullins M, Singel D et al. Adverse vascular effects of homocysteine are modulated by endotheliumderived relaxing factor and related oxides of nitrogen. J Clin Invest 1993; 91:308-318.

200 Upchurch GRJ, Welch GN, Fabian AJ, Freedman JE, Johnson JL, Keaney JFJ et a1. Homocyst(e)ine decreases bioavailable nitric oxide by a mechanism involving glutathione peroxidase. $\mathrm{J}$ Biol Chem 1997; 272:17012-17017.

201 Lang D, Kredan MB, Lewis MJ. Homocysteineinduced endothelial superoxide anion production is inhibited by tetrahydrobiopterin and folate. Circulation 1999; 100 (Suppl 1):411.

202 D'Angelo A, Selhub J. Homocysteine and thrombotic disease. Blood 1997; 90:1-11.

203 Ross R. Atherosclerosis - an inflammatory disease. N Engl J Med 1999; 340:115-126.

204 Harjai KJ. Potential new cardiovascular risk factors: left ventricular hypertrophy, homocysteine, lipoprotein(a), triglycerides, oxidative stress, and fibrinogen. Ann Intern Med 1999; 131:376-386.

205 Usui M, Matsuoka H, Miyazaki H, Ueda S, Okuda $\mathrm{S}$, Imaizumi T. Endothelial dysfunction by acute hyperhomocyst(e)inaemia: restoration by folic acid. Clin Sci Colch 1999; 96:235-239.

206 Verhaar MC, Wever RMF, Kastelein JJ, van Dam T, Koomans HA, Rabelink TJ. 5-methyltetrahydrofolate, the active form of folic acid, restores endothelial function in familial hypercholesterolemia. Circulation 1998; 97:237-241.

207 Wilmink HW, Stroes ES, Erkelens WD, Gerritsen WB, Wever R, Banga JD et al. Influence of folic acid on postprandial endothelial dysfunction. Arterioscler Thromb Vasc Biol 2000; 20:185-188.

208 Stroes ES, van Faassen EE, Yo M, Martasek P, Boer $\mathrm{P}$, Govers $\mathrm{R}$ et al. Folic acid reverts dysfunction of endothelial nitric oxide synthase. Circ Res 2000; 86:1129-1134.

209 Jeremy JY, Rowe D, Emsley AM, Newby AC. Nitric oxide and the proliferation of vascular smooth muscle cells. Cardiovasc Res 1999; 43:580-594.

210 Kojda G, Harrison D. Interactions between NO and reactive oxygen species: pathophysiological importance in atherosclerosis, hypertension, diabetes and heart failure. Cardiovasc Res 1999; 43:562-571.

211 Wever RMF, Lüscher TF, Cosentino F, Rabelink TJ. Atherosclerosis and the two faces of endothelial nitric oxide synthase. Circulation 1998; 97:108-112.

212 Harrison DG. Cellular and molecular mechanisms of endothelial cell dysfunction. J Clin Invest 1997; 100:2153-2157.
213 Walter R, Mark M, Reinhart WH. Pharmacological concentrations of arginine influence human whole blood viscosity independent of nitric oxide synthase activity in vitro. Biochem Biophys Res Commun 2000; 269:687-691.

214 Tsikas D, Boger RH, Sandmann J, Bode-Böger $\mathrm{SM}$, Frohlich JC. Endogenous nitric oxide synthase inhibitors are responsible for the L-arginine paradox. FEBS Lett 2000; 478:1-3.

215 Leiper J, Vallance P. Biological significance of endogenous methylarginines that inhibit nitric oxide synthases. Cardiovasc Res 1999; 43:542548.

216 Maxwell AJ, Cooke JP. Cardiovascular effects of L-arginine. Curr Opin Nephrol Hypertens 1998; 7:63-70.

217 Schiekofer S, Balletshofer B, Andrassy M, Bierhaus A, Nawroth PP. Endothelial dysfunction in diabetes mellitus. Semin Thromb Hemost 2000; 26:503-511.

218 De Vriese AS, Verbeuren TJ, Van de Voorde J, Lameire NH, Vanhoutte PM. Endothelial dysfunction in diabetes. Br $\mathrm{J}$ Pharmacol 2000; 130:963974.

219 Pieper GM. Review of alterations in endothelial nitric oxide production in diabetes: protective role of arginine on endothelial dysfunction. Hypertension 1998; 31:1047-1060.

220 Cosentino F, Hishikawa K, Katusic ZS, Lüscher TF. High glucose increases nitric oxide synthase expression and superoxide anion generation in human aortic endothelial cells. Circulation 1997; 96:25-28.

221 Shinozaki K, Kashiwagi A, Nishio Y, Okamura T, Yoshida Y, Masada M et al. Abnormal biopterin metabolism is a major cause of impaired endothelium-dependent relaxation through nitric oxide/O2imbalance in insulin-resistant rat aorta. Diabetes $1999 ; 48: 2437-2445$.

222 Wu G, Meininger CJ. Impaired arginine metabolism and NO synthesis in coronary endothelial cells of the spontaneously diabetic BB rat. Am J Physiol 1995; 269:H1312-H1318.

223 Hamon CG, Cutler P, Blair JA. Tetrahydrobiopterin metabolism in the streptozotocin induced diabetic state in rats. Clin Chim Acta 1989; 181:249-253.

224 Pieper GM. Acute amelioration of diabetic endothelial dysfunction with a derivative of the nitric oxide synthase cofactor, tetrahydrobiopterin. J Cardiovasc Pharmacol 1997; 29:8-15.

225 Shinozaki K, Nishio Y, Okamura T, Yoshida Y, Maegawa $\mathrm{H}$, Kojima $\mathrm{H}$ et al. Oral administration of tetrahydrobiopterin prevents endothelial dysfunction and vascular oxidative stress in the aortas of 
insulin-resistant rats. Circ Res 2000; 87:566-573.

226 Meininger CJ, Marinos RS, Hatakeyama K, Martinez-Zaguilan R, Rojas JD, Kelly KA et al. Impaired nitric oxide production in coronary endothelial cells of the spontaneously diabetic BB rat is due to tetrahydrobiopterin deficiency. Biochem J 2000; 349:353-356.

227 Verma S, Yao L, Stewart DJ, Dumont AS, Anderson TJ, McNeill JH. Endothelin antagonism uncovers insulin-mediated vasorelaxation in vitro and in vivo. Hypertension 2001; 37:328-333.

228 Tseng CC, Hattori Y, Kasai K, Nakanishi N, Shimoda SI. Decreased production of nitric oxide by LPS-treated $\mathbf{J} 774$ macrophages in high-glucose medium. Life Sci 1997; 60:PL99-PL106.

229 Pittilo RM. Cigarette smoking, endothelial injury and cardiovascular disease. Int J Exp Pathol 2000; 81:219-230.

230 Higman DJ, Strachan AM, Buttery L, Hicks RC, Springall DR, Greenhalgh RM et al. Smoking impairs the activity of endothelial nitric oxide synthase in saphenous vein. Arterioscler Thromb Vasc Biol 1996; 16:546-552.

231 Spieker LE, Noll G, Ruschitzka FT, Maier W, Lüscher TF. Working under pressure: the vascular endothelium in arterial hypertension. J Hum Hypertens 2000; 14:617-630.

232 Puddu P, Puddu GM, Zaca F, Muscari A. Endothelial dysfunction in hypertension. Acta Cardiol 2000; 55:221-232.

233 Cosentino F, Patton S, d'Uscio LV, Werner ER, Werner-Felmayer G, Moreau $P$ et al. Tetrahydrobiopterin alters superoxide and nitric oxide release in prehypertensive rats. $\mathrm{J}$ Clin Invest 1998; 101:1530-1537.

234 Higashi Y, Sasaki S, Nakagawa K, Matsuura H, Kajiyama G, Oshima T. Tetrahydrobiopterin improves impaired endothelium-dependent vasodilation in patients with essential hypertension. Circulation 1999; 100 (Suppl I):828.

235 Landmesser U, Hornig B, Drexler H. Endothelial dysfunction in hypercholesterolemia: Mechanisms, pathophysiological importance, and therapeutic interventions. Semin Thromb Hemost 2000; 26:529-537

236 Jiang JH, Valen G, Tokuno S, Thoren P, Pernow J. Endothelial dysfunction in atherosclerotic mice: improved relaxation by combined supplementation with L-arginine-tetrahydrobiopterin and enhanced vasoconstriction by endothelin. $\mathrm{Br} \mathrm{J}$ Pharmacol 2000; 131:1255-1261.

237 Gruhn N, Aldershvile J, Boesgaard S. Tetrahydrobiopterin improves endotheliumdependent vasodilation in nitroglycerin-tolerant rats. Eur J Pharmacol 2001; 416:245-249.

238 Quyyumi A. . Dakak N. Mulcahy D, Andrews NP, Husain S. Panza JA et al. Nitric oxide activity in the atherosclerotic human coronary circulation. J Am Coll Cardiol 1997; 29:308-317.

239 Tiefenbacher CP, Bleeke T, Vahl C, Amann K, Vogt A, Kübler W. Endothelial dysfunction of coronary resistance arteries is improved by tetrahydrobiopterin in atherosclerosis. Circulation 2000; 102:2172-2179.

240 Wilcox JN, Subramanian RR, Sundell CL, Tracey WR, Pollock JS, Harrison DG et al. Expression of multiple isoforms of nitric oxide synthase in normal and atherosclerotic vessels. Arterioscler Thromb Vasc Biol 1997; 17:2479-2488.

241 Oemar BS, Tschudi MR, Godoy N, Brovkovich V, Malinski T, Lüscher TF. Reduced endothelial nitric oxide synthase expression and production in human atherosclerosis. Circulation 1998; 97:24942498.

242 Buttery LD, Chester AH, Springall DR, Borland JA, Michel T, Yacoub MH et al. Explanted vein grafts with an intact endothelium demonstrate reduced focal expression of endothelial nitric oxide synthase specific to atherosclerotic sites. J Pathol 1996; 179:197-203.

243 Maier W, Cosentino F, Lütolf RB, Fleisch M, Seiler $\mathrm{C}$, Hess $\mathrm{OM}$ et al. Tetrahydrobiopterin improves endothelial function in patients with coronary artery disease. J Cardiovasc Pharmacol 2000; 35:173-178.

244 Setoguchi S, Mohri M, Hirooka Y, Ichiki T. Intracoronary tetrahydrobiopterin improves endothelial dysfunction in patients with coronary risk factors. Circulation 1999; 100 (Suppl I):7.

245 Fukuda Y, Teragawa H, Matsuda K, Miura F, Hirao $\mathrm{H}$, Yamada $\mathrm{T}$ et al. Tetrahydrobiopterin restores endothelial function in human coronary arteries in vivo. J.Am.Coll.Cardiol. 2000; 35 (Suppl A):246A.

246 Buttery LD, Springall DR, Chester AH, Evans TJ, Standfield EN, Parums DV et al. Inducible nitric oxide synthase is present within human atherosclerotic lesions and promotes the formation and activity of peroxynitrite. Lab Invest 1996; 75:77-85.

247 Esaki T, Hayashi T, Muto E, Yamada K, Kuzuya M, Iguchi A. Expression of inducible nitric oxide synthase in $\mathrm{T}$ lymphocytes and macrophages of cholesterol-fed rabbits. Atherosclerosis 1997; 128:39-46.

248 Luoma JS, Stralin P, Marklund SL, Hiltunen TP, Sarkioja T, Ylä-Herttuala S. Expression of extracellular SOD and iNOS in macrophages and smooth muscle cells in human and rabbit athero- 
sclerotic lesions: colocalization with epitopes chayacteristic of oxidized LDL and peroxynitrite-modified proteins. Arterioscler Thromb Vasc Biol 1998; 18:157-167.

249 Cromheeke KM, Kockx MM, De Meyer GR, Bosmans JM, Bult H, Beelaerts WJ et al. Inducible nitric oxide synthase colocalizes with signs of lipid oxidation/peroxidation in human atherosclerotic plaques. Cardiovasc Res 1999; 43:744-754.

250 Verma S, Lovren F, Dumont AS, Mather KJ, Maitland A, Kieser TM et al. Tetrahydrobiopterin improves endothelial function in human saphenous veins. J Thorac Cardiovasc Surg 2000; 120:668671.

251 Dulak J, Polus M, Guevara I, Polus A, Hartwich J, Dembinska-Kiec A. Regulation of inducible nitric oxide synthase (iNOS) and GTP cyclohydrolase I (GTP-CH I) gene expression by ox-LDL in rat vascular smooth muscle cells. J Physiol Pharmacol 1997; 48:689-697.

252 Ferrari R, Bachetti T, Agnoletti L, Comini L, Curello S. Endothelial function and dysfunction in heart failure. Eur Heart J 1998; 19 (Suppl G):G41G47.

253 Heitzer T, Münzel T. Lack of effect of tetrahydrobiopterin and vitamin $\mathrm{C}$ on endothelial function in patients with congestive heart failure. Circulation 1998; 98 (Suppl I):318.

254 Setoguchi S, IHirooka Y, Eshima K, Ide T, Tsutsui H. Tetrahydrobiopterin improves impaired endothelium-dependent vasodilation in patients with chronic heart failure. Circulation 1999; 100 (Suppl I):554.

255 Shintaku $H$, Inoue $\mathrm{K}$, Okamura $\mathrm{T}$, Choi KY, Haraguchi M, Konishi $M$ et al. Anti-hypertensive effects of tetrahydrobiopterin (BH4) on DOCA-salt hypertension in rats. In: Pfleiderer $\mathrm{W}$, Rokos $\mathrm{H}$, editors. Chemistry and Biology of Pteridines and Folates 1997. Berlin, Vienna: Blackwell Wiss.Verl., 1997: 765-769.

256 Schmid RA, Hillinger S, Walter R, Zollinger A, Stammberger U, Speich $\mathrm{R}$ et al. The nitric oxide synthase cofactor tetrahydrobiopterin reduces allograft ischemia-reperfusion injury after lung transplantation. J Thorac Cardiovasc Surg 1999; 118:726-732.

257 Kakoki M, Hirata Y, Hayakawa H, Suzuki E, Nagata D, Tojo A et al. Effects of tetrahydrobiopterin on endothelial dysfunction in rats with ischemic acute renal failure. J Am Soc Nephrol 2000; 11:301-309.

258 Ishii M, Shimizu S, Nawata S, Kiuchi Y, Yamamoto $\mathrm{T}$. Involvement of reactive oxygen species and nitric oxide in gastric ischemia-reper- fusion injury in rats: protective effect of tetrahydrobiopterin. Dig Dis Sci 2000; 45:93-98.

259 Tiefenbacher CP, Chilian WM, Mitchell M, DeFily DV. Restoration of endothelium-dependent vasodilation after reperfusion injury by tetrahydrobiopterin. Circulation 1996; 94:1423-1429.

260 Huk I, Nanobashvili J, Neumayer C, Fugl A, Prager M, Brovkovych V et al. Tetrahydrobiopterin and L-arginine in the ischemia/reperfusion injury. Shock 1999; 12 (Suppl 1):40-41.

261 Tiefenbacher CP, Menzel S, Lee C. Reduction of myocardial infarct size and improvement of myocardial stunning by tetrahydrobiopterin FASEB J. 2000; 14:A423.

262 Giraldez RR, Panda A, Xia X, Sanders SP, Zweier $\Omega$ L. Decreased nitric-oxide synthase activity causes impaired endothelium-dependent relaxation in the postischemic heart. J Biol Chem 1997; 272:2142021426.

263 Channon KM, Qian H, George SE. Nitric oxide synthase in atherosclerosis and vascular injury: insights from experimental gene therapy. Arterioscler Thromb Vasc Biol 2000; 20:18731881 .

264 Kullo IJ, Schwartz RS, Pompili VJ, Tsutsui M, Milstien S, Fitzpatrick LA et al. Expression and function of recombinant endothelial NO synthase in coronary artery smooth muscle cells. Arterioscler Thromb Vasc Biol 1997; 17:24052412.

265 Tzeng E, Shears LLI, Robbins PD, Pitt BR, Geller DA, Watkins SC et al. Vascular gene transfer of the human inducible nitric oxide synthase: characterization of activity and effects on myointimal hyperplasia. Mol Med 1996; 2:211-225.

266 Kibbe MR, Nie S, Yoneyama T, Hatakeyama K, Lizonova A, Kovesdi I et al. Optimization of ex vivo inducible nitric oxide synthase gene transfer to vein grafts. Surgery $1999 ; 126: 323-329$.

267 Stoodley M, Weihl CC, Zhang ZD, Lin G, Johns LM, Kowalczuk A et al. Effect of adenovirusmediated nitric oxide synthase gene transfer on vasospasm after experimental subarachnoid hemorrhage. Neurosurgery 2000; 46:1193-1202.

268 Neufeld G, Cohen T, Gengrinovitch S, Poltorak Z. Vascular endothelial growth factor (VEGF) and its receptors. FASEB J 1999; 13:9-22.

269 Dulak J, Jozkowicz A, Dembinska KA, Guevara I, Zdzienicka A, Zmudzinska GD et al. Nitric oxide induces the synthesis of vascular endothelial growth factor by rat vascular smooth muscle cells. Arterioscler Thromb Vasc Biol 2000; 20:659-666. 270 Yang R, Thomas GR, Bunting S, Ko A, Ferrara N, Keyt $B$ et al. Effects of vascular endothelial growth 
factor on hemodynamics and cardiac performance. J Cardiovasc Pharmacol 1996; 27:838-844.

271 Morbidelli L, Chang CH, Douglas JG, Granger HJ, Ledda F, Ziche M. Nitric oxide mediates mitogenic effect of VEGF on coronary venular endothelium. Am J Physiol 1996; 270:H411-H415.

$272 \mathrm{Wu}$ HM, Huang Q, Yuan Y, Granger HJ. VEGF induces NO-dependent hyperpermeability in coronary venules. Am J Physiol 1996; 271:H2735H2739.

273 Ziche M, Morbidelli L, Choudhuri R, Zhang HT, Donnini S, Granger HJ et al. Nitric oxide synthase lies downstream from vascular endothelial growth factor-induced but not basic fibroblast growth factor-induced angiogenesis. J Clin Invest 1997; 99:2625-2634.

274 Malavaud B, Tack I, Jonca F, Praddaude F, Moro F, Ader JL et al. Activation of Flk-1/KDR mediates angiogenesis but not hypotension. Cardiovasc Res $1997 ; 36: 276-281$.

275 van der Zee R, Murohara T, Luo Z, Zollmann F, Passeri J, Lekutat $C$ et al. Vascular endothelial growth factor/vascular permeability factor augments nitric oxide release from quiescent rabbit and human vascular endothelium. Circulation 1997; 95:1030-1037.

276 Horowitz JR, Rivard A, van der Zee R, Hariawala $\mathrm{M}$, Sheriff DD, Esakof DD et al. Vascular endothelial growth factor/vascular permeability factor produces nitric oxide-dependent hypotension. Evidence for a maintenance role in quiescent adult endothelium. Arterioscler Thromb Vasc Biol 1997; 17:2793-2800.

277 Murohara T, Horowitz JR, Silver M, Tsurumi Y, Chen D, Sullivan A et al. Vascular endothelial growth factor/vascular permeability factor enhances vascular permeability via nitric oxide and prostacyclin. Circulation 1998; 97:99-107.

278 Parenti A, Morbidelli L, Cui XL, Douglas JG, Hood JD, Granger HJ et al. Nitric oxide is an upstream signal of vascular endothelial growth factor-induced extracellular signal-regulated kinase 12 activation in postcapillary endothelium. $\mathrm{J}$ Biol Chem 1998; 273:4220-4226.

279 Papapetropoulos A, Garcia-Cardena G, Madri JA, Sessa WC. Nitric oxide production contributes to the angiogenic properties of vascular endothelial growth factor in human endothelial cells. J Clin Invest 1997; 100:3131-3139

280 Hood JD, Meininger CJ, Ziche M, Granger HJ. VEGF upregulates ecNOS message, protein, and NO production in human endothelial cells. Am J Physiol 1998; 274:H1054-H1058.

281 Ylä-Herttuala S, Martin JF. Cardiovascular gene therapy. Lancet 2000; 355:213-222.

282 Murohara T, Asahara T, Silver M, Bauters C, Masuda H, Kalka $\mathrm{C}$ et al. Nitric oxide synthase modulates angiogenesis in response to tissue ischemia. J Clin Invest 1998; 101:2567-2578.

283 Rimar S, Gillis CN. Nitric oxide and experimental lung injury. In: Zapol WM, Bloch KD, editors. Nitric Oxide and the Lung. New York: Marcel Dekker Inc., 1997: 165-183.

284 Hampl V, Herget J. Role of nitric oxide in the pathogenesis of chronic pulmonary hypertension. Physiol Rev 2000; 80:1337-1372.

285 Chen YF, Oparil S. Endothelial dysfunction in the pulmonary vascular bed. Am J Med Sci 2000; 320:223-232.

286 Adnot S, Raffestin B, Eddahibi S, Defouilloy C, Andrivet $\mathrm{P}$. Nitric oxide and chronic hypoxic pulmonary hypertension: animal models and human studies. In: Zapol WM, Bloch KD, editors. Nitric Oxide and the Lung. New York: Marcel Dekker Inc., 1997: 137-163.

287 Giaid A, Saleh D. Reduced expression of endothelial nitric oxide synthase in the lungs of patients with pulmonary hypertension. N Engl J Med 1995; 333:214-221.

288 Robbins RA, Jinkins PA, Bryan TW, Prado SC, Milligan SA. Methotrexate inhibition of inducible nitric oxide synthase in murine lung epithelial cells in vitro. Am J Respir Cell Mol Biol 1998; 18:853859 